\title{
EPMA monazite geochronology of the granulites from Daltonganj, eastern India and its correlation with the Rodinia supercontinent
}

\author{
Ravi Ranjan KumaR* and S B Dwivedi \\ Department of Civil Engineering, Indian Institute of Technology (BHU), Varanasi 221 005, India. \\ ${ }^{*}$ Corresponding author. e-mail: ravirk.rs.civ16@itbhu.ac.in
}

MS received 20 June 2018; revised 26 May 2019; accepted 18 June 2019

We report the monazite dates of the granulites from Daltonganj (Palamau), Chhotanagpur granite-gneiss complex (CGGC) which covers the significant part of the granulite blocks in central India by using an electron micro probe analyser dating. The monazite grain varies between 70 and $80 \mu \mathrm{m}$ and shows the distribution of $\mathrm{U}, \mathrm{Th}$ and $\mathrm{Pb}$ in all monazite grains of both samples. Two different dates were obtained from different monazite grains; the first age suggests that the granulite from CGGC preserves the first remnant of the protolith of the Mesoproterozoic era at $\sim 1424 \mathrm{Ma}$ and second one at $\sim 972 \mathrm{Ma}$ which provides evidence of metamorphism of the protolith. The CGGC rocks preserve four regional metamorphic events, namely $\mathrm{M}_{1}, \mathrm{M}_{2}, \mathrm{M}_{3}$ and $\mathrm{M}_{4}$. But in this work, two different ages from the Daltonganj granulites were obtained which are similar to the $\mathrm{M}_{2}(<1500 \mathrm{Ma}$, i.e., the age of protolith of the granulitic gneiss) and $\mathrm{M}_{3}$ (1200-930 Ma) metamorphic events as reported in the CGGC. The $\mathrm{M}_{3}$ metamorphism attained its average $P-T$ condition at $\sim 7.35 \mathrm{kbar} / 792^{\circ} \mathrm{C}$, and it represents the prograde metamorphic event. The $\mathrm{M}_{3}$ metamorphic event supported the Grenville-orogeny, and it was responsible for the metamorphism of the magmatic protolith of granulitic gneiss from the CGGC at the time of amalgamation of the Rodinia supercontinent. The Rodinia assembly had occurred through the global Grenville-orogenic events between 1100 and $900 \mathrm{Ma}$, with continental blocks which exist at that time.

Keywords. Monazite dating; CGGC; $P-T$ condition; Rodinia assembly.

\section{Introduction}

Electron micro probe analyser (EPMA) monazite dating has been extensively used for metamorphic and igneous rocks from the last few decades (Suzuki and Adachi 1991, 1994; Montel et al. 1994, 1996; Cocherie et al. 1997). An electron microprobe of thorium (Th)-uranium (U)-lead $(\mathrm{Pb})$ monazite dating principal was applied to obtain the age of granulite rocks from Daltonganj.
Monazite mineral is a phosphate of light weight rare-earth element $\left[(\mathrm{LREE}) \mathrm{PO}_{4}\right]$, with abundant $\mathrm{U}, \mathrm{Th}$ and little $\mathrm{Pb}$ (Parrish 1990). The rapid accumulation of radiogenic lead $(* \mathrm{~Pb})$, to a required level, is possible, which can be analysed with an electron probe (Montel et al. 1996). Monazite dating with the help of an electron microprobe has been performed by several researchers based on the abundance of $\mathrm{Th}, \mathrm{U}$ and $\mathrm{Pb}$ (Suzuki and Adachi 1991, 1994; Montel et al. 1996; Braun 
et al. 1998; Williams et al. 1999). The EPMAmonazite dating technique is a reliable technique to identify the recorded history of polymetamorphic events (Rosa-Costa et al. 2008; Karmakar et al. 2011; Prabhakar 2013; Bhowmik et al. 2014). Petrogenetic considerations and the textural relations of mineral phases in the granulite of the Chhotanagpur granite-gneiss complex (CGGC) suggest that $\mathrm{M}_{1}(1700-1600 \mathrm{Ma})$ and $\mathrm{M}_{4}(1000-900$ $\mathrm{Ma})$ are the prograde metamorphic events, which are separated by $\mathrm{M}_{2}$ and $\mathrm{M}_{3}$ (1100-1400 Ma) retrograde metamorphic events (Maji et al. 2008), and they are of younger age (830-600 Ma), the cause of which remains unexplored. Furthermore, Sanyal and Sengupta (2012) documented the four metamorphic stages $\left(\mathrm{M}_{1}-\mathrm{M}_{4}\right)$, where the $\mathrm{M}_{1}$ metamorphic stage occurred around $1870 \mathrm{Ma}$ and successively followed by the $\mathrm{M}_{2}$ metamorphic phase between 1660 and $1270 \mathrm{Ma}$, the $\mathrm{M}_{3}$ phase was recorded between 1200 and $930 \mathrm{Ma}$, followed by an $\mathrm{M}_{4}$ event at $870-780 \mathrm{Ma}$. The detail of the four metamorphic stages along with their age and technique of dating by various authors in CGGC is given in table 1.

Chatterjee et al. (2010) correlated the Precambrian eastern Indian terrain with the Sausar mobile belt in central India and the Shillong-Meghalaya granulite belt from the northeastern part of India which can be used as an essential tool for the India-Australia-Antarctica correlation. The breakdown of the Columbia supercontinent was initiated during the Mesoproterozoic era which leads to the reconstruction of the Rodinia supercontinent between 1200 and 900 Ma (Dalziel 1991; Hoffman 1991; Moores 1991; Li et al. 2008; Bhowmik et al. 2010). Greater India is shown to have been in contact with the Antarctica-Australia Peri-Rodinian margin (Li et al. 2008) supported by the petrological and geochronological setting of the Eastern Ghats mobile belt (EGMB) of India and the Rayner province of Antarctica (Dalziel 1991; Yoshida et al. 1992; Shaw et al. 1997; Mezger and Cosca 1999; Dasgupta and Sengupta 2003). 1000-900 Ma age was preserved in older high-pressure metamorphic rocks of CGGC which is assumed to be the extension of central Indian tectonic zone (CITZ), and act as a suture zone when the SIB, NIB and MC were joined together during the Stenian-Tonian orogenesis (Bhowmik et al. 2010). Polymetamorphic events were preserved in the SIB, CITZ and CGGC with similarity with respect to petrological and geochronological properties (Chatterjee et al. 2008; Maji et al. 2008; Sanyal and Sengupta 2012). This study deals with the electron microprobe monazite dating of the garnet-hypersthene-gedrite-cordierite gneiss and the garnet-gedrite-cordierite-biotite gneiss from Daltonganj (Palamau) in the CGGC. We have documented the evidence of the tectono-metamorphic event from the north-western part of CGGC with the help of petrological, geothermobarometry and EPMA-monazite dating techniques. We have also striven to unravel the geodynamic implications of metamorphism in the granulite facies rocks of CGGC and their correlation to global-scale Grenvillian orogenesis suturing in the peninsular part of India with the Rodinia assembly.

\section{Geological background}

The area under investigation (latitude $23^{\circ} 54^{\prime} 50^{\prime \prime}-$ $23^{\circ} 58^{\prime} 30^{\prime \prime} \mathrm{N}$; longitude $84^{\circ} 2^{\prime}-84^{\circ} 06^{\prime} 30^{\prime \prime} \mathrm{E}$ ) belongs to the western part of CGGC. It covers a vast area of about $100,000 \mathrm{~km}^{2}$ and extends in the east-west from the provinces of Jharkhand, Orissa, Chhattisgarh, Madhya Pradesh and West Bengal and the south-eastern part of Uttar Pradesh. The CGGC includes multiple generations of mafic intrusives, namely meta-dolerite and norites to gabbros in which the corona texture is often demarcated at several places, especially in Purulia, Dumka and Daltonganj. This gneissic complex shows composite character consisting mainly of granitoid gneisses, migmatites and massive granites with enclaves of metasedimentary and meta-igneous rocks and intrusive basic and intermediate rocks (Ghose 1983, 1992; Chatterjee and Ghose 2011; Sanyal and Sengupta 2012; Yadav et al. 2016; Dwivedi et al. 2019 and references therein). The medium- to high-grade metamorphic terrain of CGGC mainly contains amphibolite to granulite facies rocks, which is sandwiched between the medium- to low-grade mobile belts. Here, the first one is located in the southern margin of CGGC and known as the North Singhbhum mobile belt, and it consists of the volcanic intrusive as well as sedimentary sequences (Saha 1994). The other mobile belt is located on the northern margin, and it extends from the north-western part of CGGC, which is called the Mahakoshal mobile belt. It preserves the metasediments, granitoids and mafic-ultramafic rocks (Roy and 
Devarajan 2000). The CGGC has a broad history of two high-grade metamorphic events during the Mesoproterozoic and Grenvillian ages, and both these events recorded in the entire metamorphosed rock lie within CGGC (Pandey et al. 1986a, b; Ray Barman and Bishui 1994; Chatterjee et al. 2008; Maji et al. 2008; Sanyal and Sengupta 2012; Mukherjee et al. 2017). The north-western part of CGGC (Daltonganj) consists of granulite facies rocks, charnockite and migmatitic-tonalite-granodiorite-granite gneisses (Rode 1948; Dwivedi et al. 2019). The porphyritic granitic magmatism $(\sim 1660 \pm 17 \mathrm{Ma})$ was reported from the western as well as the northern part of CGGC (Chatterjee and Ghose 2011; Saikia et al. 2017). The NE part of the CGGC is dominated by charnockitic gneisses as country rocks, and it was metamorphosed to amphibole-biotite gneiss. The $1447 \pm 11 \mathrm{Ma}$ age was obtained by $\mathrm{U}-\mathrm{Pb}$ zircon dating from the protolith of the charnockitic gneisses and further high-grade metamorphism was recorded at $943 \mathrm{Ma}$ from the migmatitic charnockitic gneiss under pressuretemperature $(P-T)$ condition $\sim 9$ kbar and $780-800^{\circ} \mathrm{C}$ (Mukherjee et al. 2017, 2018). Magmatic events are recorded from all parts of the CGGC during the Neoproterozoic era, which includes (a) partial melting and intrusive grey granite at $1005 \pm 51 \mathrm{Ma}$ and pink granite intrusion at $815 \pm 47 \mathrm{Ma}$ (Singh and Krishna 2009) and (b) granite intrusion emplaced at $975 \mathrm{Ma}$ from Daltonganj of the western CGGC (Chatterjee and Ghose 2011). The geological map (figure 1a) represents the study area (Daltonganj) with geochronological age distribution at different locations within the CGGC, and the enlarged geological map of the study area is shown in figure 1(b).

\section{Analytical techniques}

The analytical work was performed using an EPMA on a CAMECA SX five instrument at the DST-SERB National Facility, Department of Geology (CAS), Institute of Science, BHU. The thin polished section was coated with a $20 \mathrm{~nm}$ thin layer of carbon for electron probe microanalyses using a LEICA-EM ACE200 carbon coater instrument. The EPMA instrument CAMECA SX Five was operated with SX Five software at an accelerated voltage of $15 \mathrm{kV}$ and a current of $200 \mathrm{nA}$ with a $\mathrm{LaB}_{6}$ source in the electron gun for electron beam generation, which is based on a new analytical protocol for the $\mathrm{U}-\mathrm{Th}-\mathrm{Pb}$ chemical dating of monazite (Pandey et al. 2019). Andradite is used as a natural silicate mineral to verify crystal positions by using an internal standard (SP2-LiF, SP3-LPET, SP4LTAP and SP5-PET) with suitable wavelength dispersive spectrometers (SP\#) using the CAMECA SX-Five instrument. The following $\mathrm{X}$-ray lines were used in the analyses: $\mathrm{F}-\mathrm{K} \alpha$, $\mathrm{Na}-\mathrm{K} \alpha, \mathrm{Mg}-\mathrm{K} \alpha, \mathrm{Al}-\mathrm{K} \alpha, \mathrm{Si}-\mathrm{K} \alpha, \mathrm{P}-\mathrm{K} \alpha, \mathrm{Cl}-\mathrm{K} \alpha$, $\mathrm{K}-\mathrm{K} \alpha, \mathrm{Ca}-\mathrm{K} \alpha$, Ti-K $\alpha, \mathrm{Cr}-\mathrm{K} \alpha, \mathrm{Mn}-\mathrm{K} \alpha, \mathrm{Fe}-\mathrm{K} \alpha$, $\mathrm{Ni}-\mathrm{K} \alpha$ and $\mathrm{Ba}-\mathrm{L} \alpha$. Natural mineral standards: fluorite, halite, periclase, corundum, wollastonite, apatite, orthoclase, rutile, chromite, rhodonite, hematite and barite; $\mathrm{Ni}$ pure metal standard was supplied by CAMECA-AMETEK which was used for routine calibration and quantification. Quantification of rare-earth element (REE) analysis in monazite mineral phases and $\mathrm{U}$, Th and $\mathrm{Y}$ elemental X-ray mapping of monazite grains were obtained at an accelerating voltage of $20 \mathrm{kV}$, and currents of a beam are $200 \mathrm{nA}$, at $0.5 \mu \mathrm{m} /$ pixel spatial resolution. The following X-ray lines were used in the analyses: $\mathrm{Y}-\mathrm{L} \alpha, \mathrm{La}-\mathrm{L} \alpha, \mathrm{Ce}-\mathrm{L} \alpha$, $\operatorname{Pr}-\mathrm{L} \alpha, \quad \mathrm{Nd}-\mathrm{L} \alpha, \mathrm{Sm}-\mathrm{L} \alpha, \mathrm{Eu}-\mathrm{L} \alpha, \mathrm{Th}-\mathrm{M} \alpha$ and $\mathrm{U}-\mathrm{M} \alpha$. All REE analysis was carried out on a LiF crystal attached with SP2 and $\mathrm{Pb}$, Th and U were analysed with an LPET crystal connected with the SP3 spectrometer in a CAMECA-SX five EPMA instrument. Synthetic glass standards of all REE (La to U) supplied by CAMECAAMETEK were used for routine calibration and quantification.

Scanning electron microscope (SEM) analysis was performed at the DST-SERB National Facility, Department of Geology (CAS), Institute of Science, BHU. The SEM instrument was operated at an accelerated voltage of $15 \mathrm{kV}$ and a current of $200 \mathrm{nA}$.

\section{Petrography and mineral chemistry}

Different samples were collected from Datam and Mahawat Muria localities, which lie in the southwest of Daltonganj within CGGC (figure 1b). In this study, two rock samples (R-91-97 and R-9196) were selected for the analytical purpose after the detailed petrographic study from collected rock samples. Representative mineral compositional data are presented in tables $2-6$. The mineral 


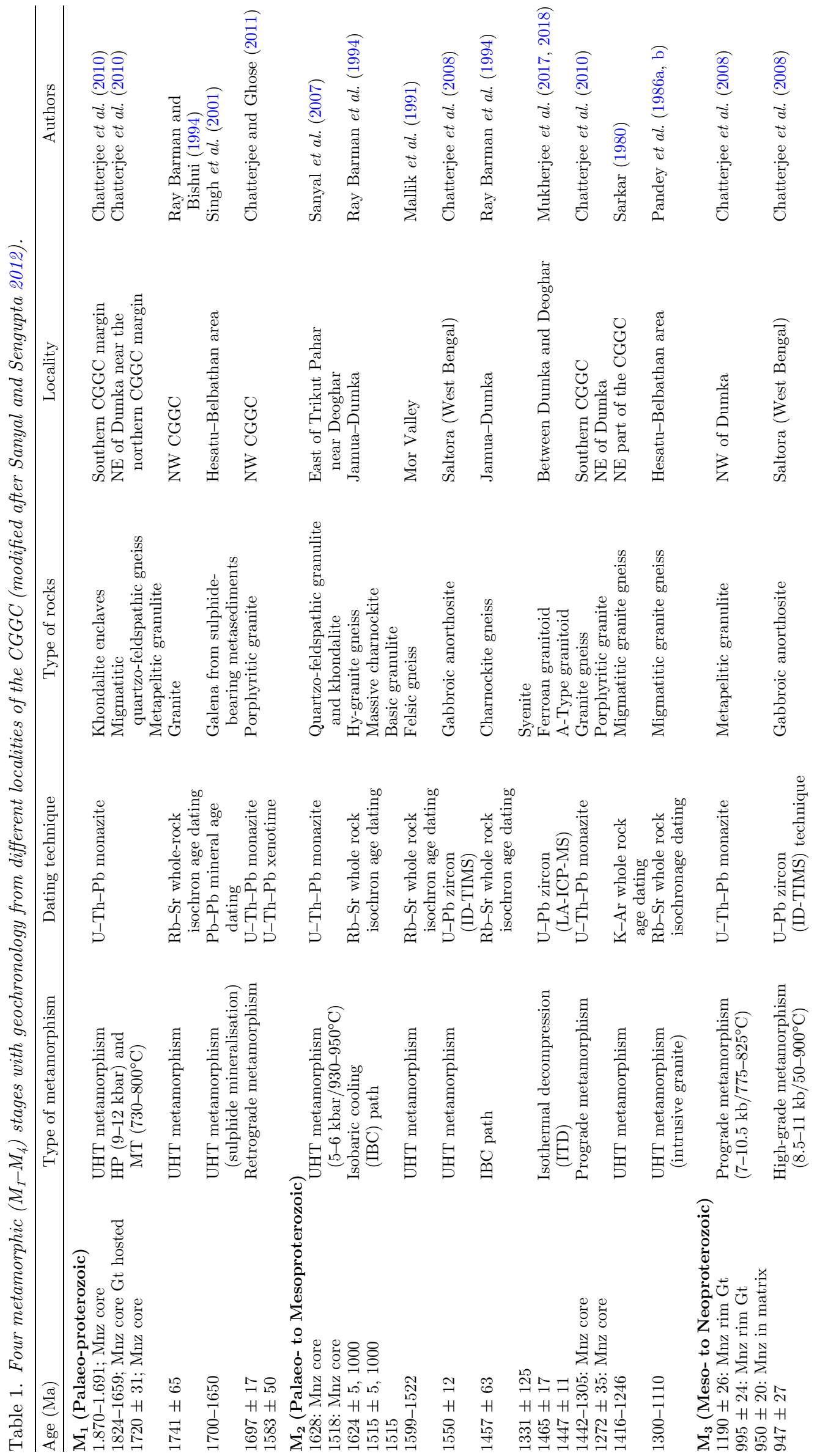




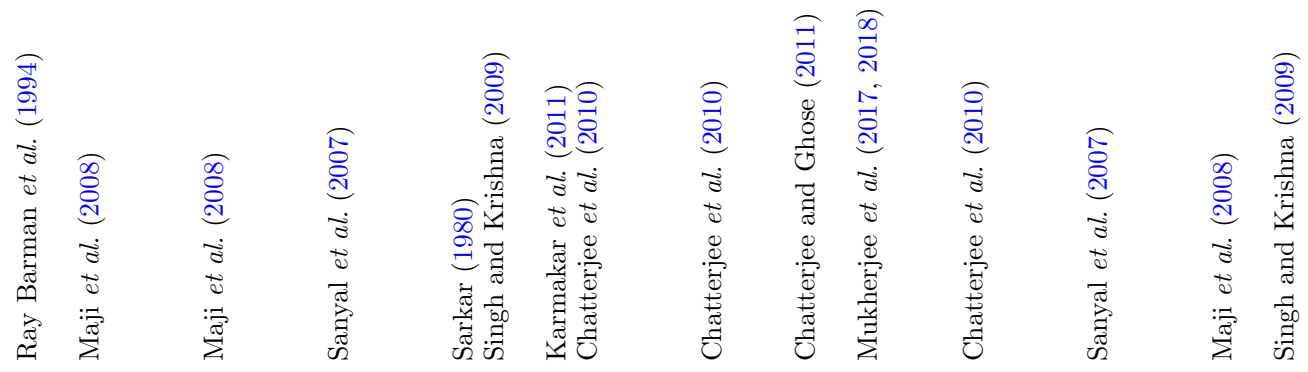

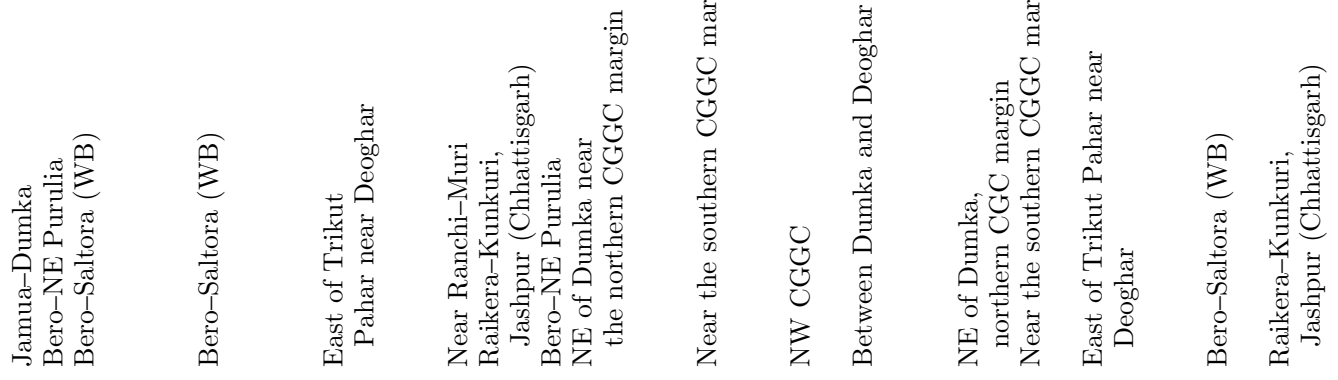

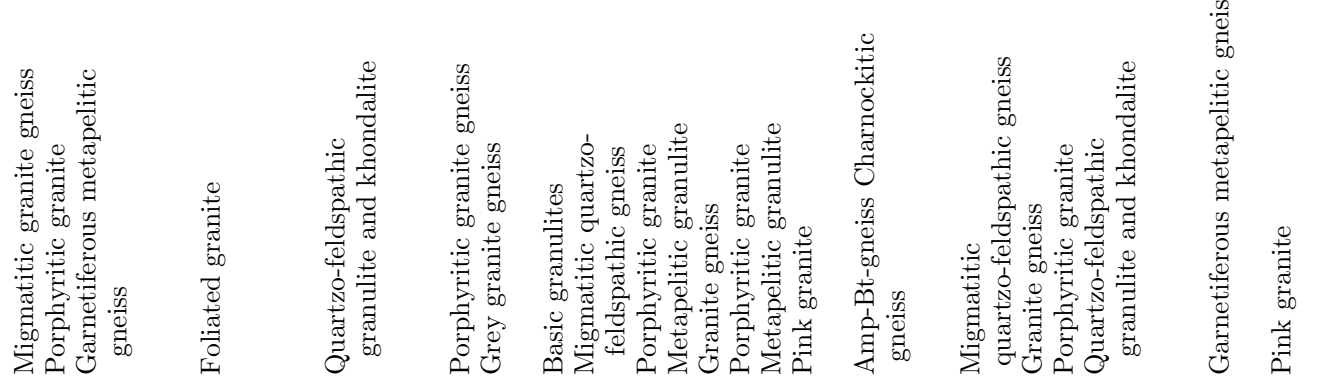

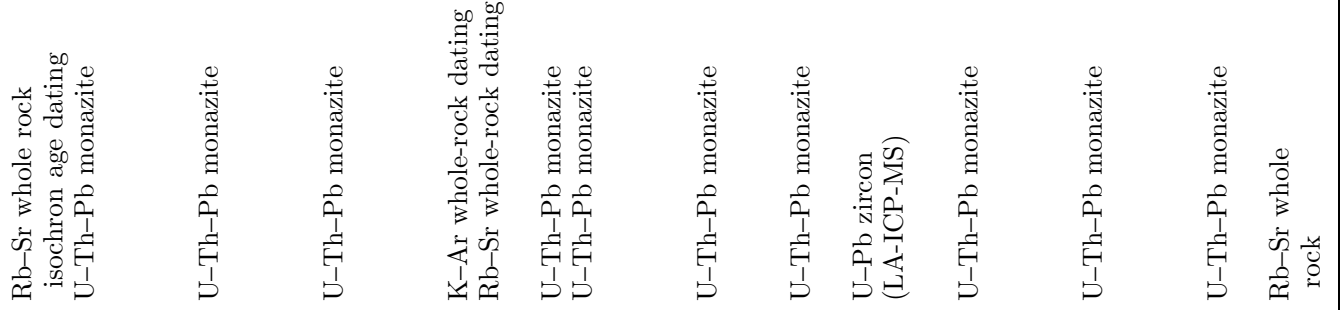

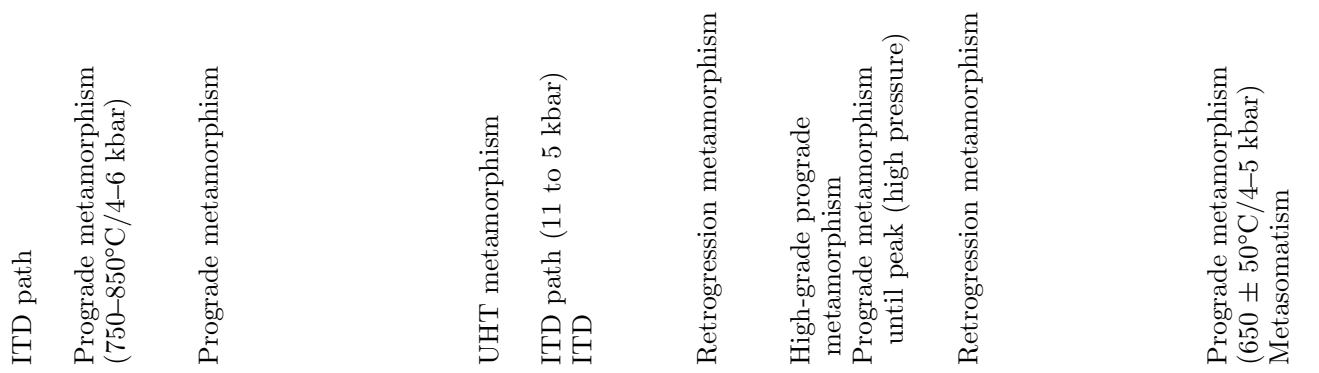

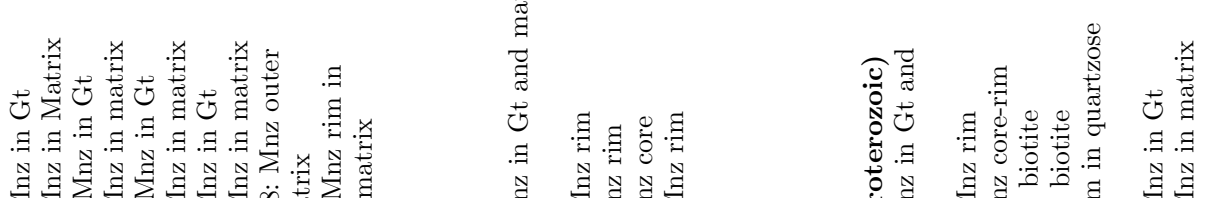

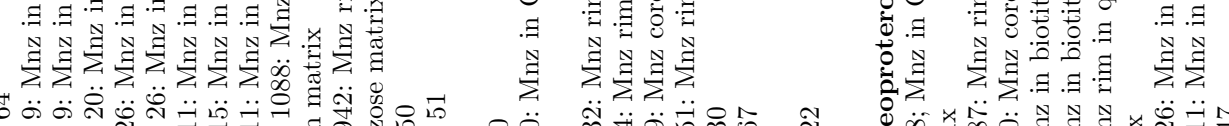

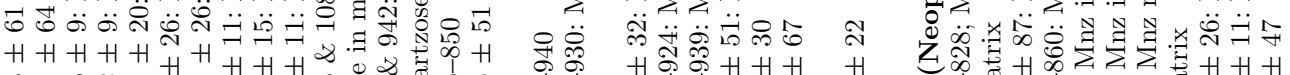

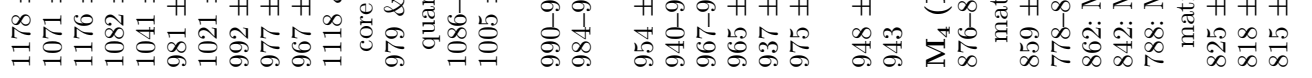



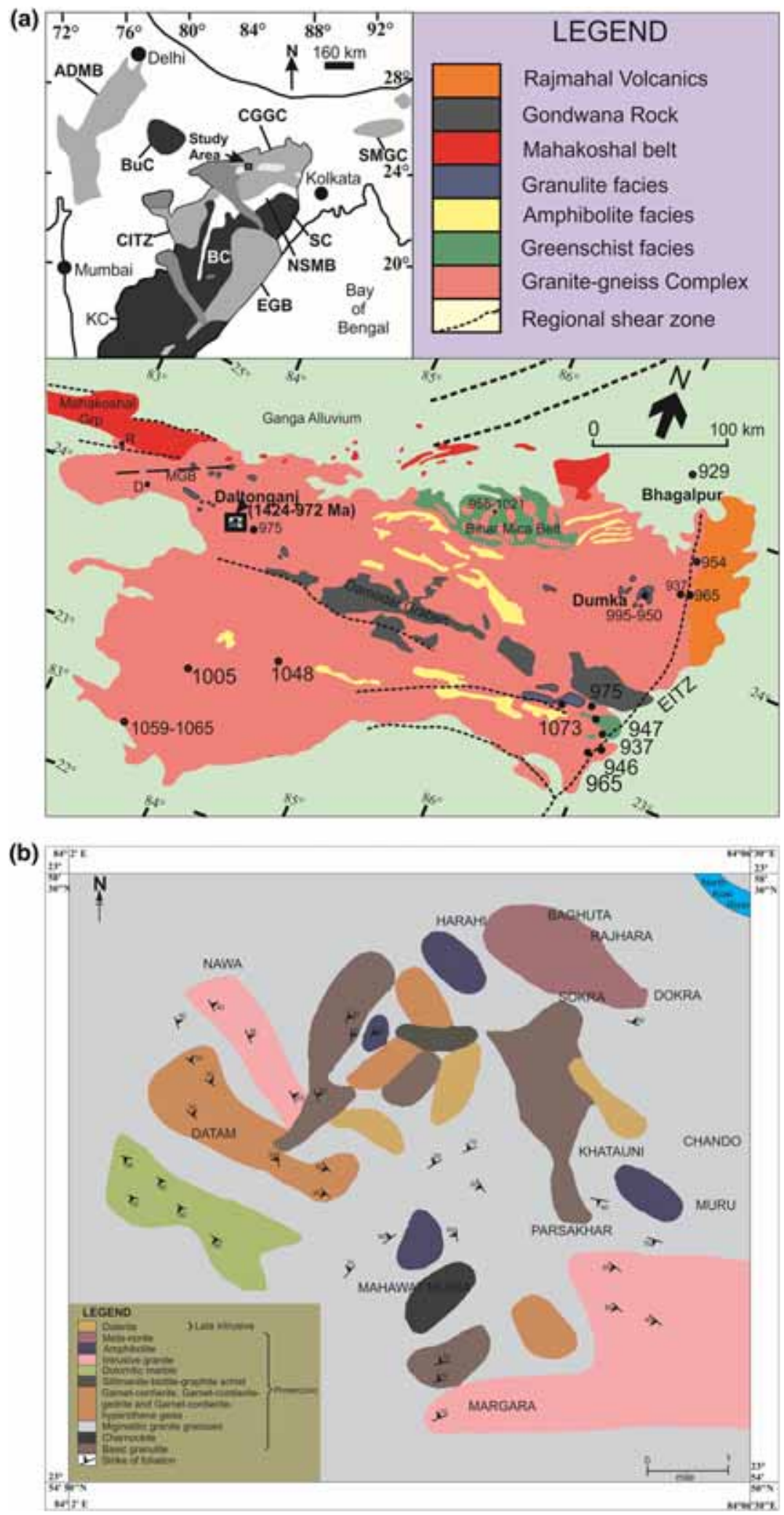

Figure 1. (a) Geological map of the CGGC (modified after Acharyya 2003; Maji et al. 2008; Chatterjee and Ghose 2011). Abbreviations: ADMB: Aravalli-Delhi mobile belt, BC: Bastar craton, BuC: Bundelkhand craton, CGGC: Chhotanagpur granite gneiss complex, CITZ: Central Indian tectonic zone, D: Dudhi, DM: Dumka, EGB: Eastern Ghats belt, KC: Karnataka craton, MGB: Makrohar granulite belt, NSMB: North Singhbhum mobile belt, R: Rihand-Renusagar area, SC: Singhbhum craton and SMGC: Shillong-Meghalaya gneissic complex. Here, the distribution of different geochronological (Grenvillian) ages in different locations, with our analysed monazite dating age is 1424-972 Ma from the Daltonganj (CGGC) India. (b) Enlarged geological map of the area around the south-west of Daltonganj, Palamau (Jharkhand) district, India. 
Table 2. Representative electron microprobe analyses and structural formula of garnet and hypersthene.

\begin{tabular}{|c|c|c|c|c|c|c|c|}
\hline \multirow[b]{3}{*}{ Domain } & \multicolumn{4}{|c|}{ Garnet } & \multirow{2}{*}{\multicolumn{3}{|c|}{$\frac{\text { Hypersthene }}{\text { Sample no. R-91-97 }}$}} \\
\hline & \multicolumn{2}{|c|}{ Sample no. R-91-97 } & \multicolumn{2}{|c|}{ Sample no. R-91-96 } & & & \\
\hline & $122 / 45$ & $122 / 20$ & $122 / 44$ & $122 / 46$ & $80 / 1$ & $155 / 1$ & $146 / 1$ \\
\hline $\mathrm{SiO}_{2}$ & 37.650 & 36.558 & 37.397 & 37.610 & 48.272 & 52.127 & 52.874 \\
\hline $\mathrm{TiO}_{2}$ & 0.005 & 0.002 & 0.005 & 0.011 & & & \\
\hline $\mathrm{Al}_{2} \mathrm{O}_{3}$ & 20.194 & 20.458 & 20.369 & 20.367 & 3.424 & 3.798 & 3.291 \\
\hline $\mathrm{FeO}$ & 34.388 & 35.823 & 34.355 & 34.388 & 28.901 & 23.976 & 23.174 \\
\hline $\mathrm{MnO}$ & 0.302 & 0.336 & 0.481 & 0.223 & & & \\
\hline $\mathrm{MgO}$ & 7.278 & 6.797 & 7.256 & 7.104 & 17.315 & 18.329 & 18.164 \\
\hline $\mathrm{CaO}$ & 0.260 & 0.239 & 0.254 & 0.247 & 0.044 & 0.054 & 0.054 \\
\hline $\mathrm{Na}_{2} \mathrm{O}$ & 0.009 & 0.002 & 0.009 & 0.023 & 0.007 & 0.568 & 0.490 \\
\hline $\mathrm{K}_{2} \mathrm{O}$ & 0.023 & 0.02 & 0.019 & 0.014 & & & \\
\hline Total & 100.109 & 100.234 & 100.143 & 99.986 & 98.151 & 98.852 & 98.371 \\
\hline $\mathrm{Si}$ & 2.963 & 2.886 & 2.942 & 2.965 & 1.897 & 1.968 & 2.000 \\
\hline $\mathrm{Al}^{\mathrm{iv}}$ & 0.000 & 0.000 & 0.000 & 0.000 & 0.103 & 0.032 & 0.000 \\
\hline$\Sigma Z$ & 2.963 & 2.886 & 2.942 & 2.965 & 2 & 2 & 2 \\
\hline $\mathrm{Al}^{\mathrm{vi}}$ & 1.874 & 1.904 & 1.889 & 1.893 & 0.056 & 0.137 & 0.148 \\
\hline $\mathrm{Ti}$ & 0.001 & 0 & 0.001 & 0.001 & & & \\
\hline $\mathrm{Fe}^{3+}$ & 0.203 & 0.326 & 0.229 & 0.180 & 0.070 & 0.000 & 0.000 \\
\hline$\Sigma Y$ & 2.078 & 2.23 & 2.119 & 2.074 & & & \\
\hline $\mathrm{Fe}^{2+}$ & 2.081 & 2.039 & 2.031 & 2.087 & 0.875 & 0.763 & 0.744 \\
\hline $\mathrm{Mn}$ & 0.020 & 0.023 & 0.032 & 0.015 & & & \\
\hline $\mathrm{Mg}$ & 0.864 & 0.8 & 0.851 & 0.834 & 1.015 & 1.031 & 1.025 \\
\hline $\mathrm{Ca}$ & 0.022 & 0.02 & 0.021 & 0.021 & 0.002 & 0.002 & 0.002 \\
\hline $\mathrm{Na}$ & 0.002 & 0 & 0.002 & 0.003 & 0.001 & 0.042 & 0.036 \\
\hline $\mathrm{K}$ & 0.002 & 0.002 & 0.002 & 0.001 & & & \\
\hline$\Sigma X$ & 2.991 & 2.884 & 2.939 & 2.961 & 2.018 & 1.975 & 1.954 \\
\hline$X_{\mathrm{Mg}}$ & 0.274 & 0.253 & 0.274 & 0.269 & 0.52 & 0.57 & 0.58 \\
\hline Pyrope & 28.90 & 27.74 & 28.96 & 28.17 & & & \\
\hline Almandine & 69.69 & 70.7 & 69.11 & 70.48 & & & \\
\hline Grossularite & 0.74 & 0.69 & 0.72 & 0.71 & & & \\
\hline Spessartite & 0.67 & 0.8 & 1.09 & 0.51 & & & \\
\hline
\end{tabular}

$X_{\mathrm{Mg}}=\mathrm{Mg} /(\mathrm{Mg}+\mathrm{Fe})$. Structural formula of garnet based on 12 oxygen basis and hypersthene based on six oxygen basis.

abbreviations used in this study are after Whitney and Evans (2010).

\subsection{Megascopic characters}

The R-91-97 contains garnet-hypersthenegedrite-cordierite gneisses, and R-91-96 consists of garnet-gedrite-cordierite-biotite gneisses, which are medium- to coarse-grained and exhibit gneissose texture with a resinous and greasy appearance. The garnet-gedrite-cordierite-biotite gneiss consists of garnet as one of their dominant minerals displaying light pinkish colour with the dark-coloured gedrite along with biotite flakes (figure 2a). Garnet-hypersthene-gedrite-cordierite gneiss contains the porphyroblastic garnet with medium- to small-size grains of hypersthene, gedrite, cordierite, biotite and quartz (figure 2b). The presence of garnet has displayed pinkish to reddish tinge to the rock. On the weathered surface of such gneisses, the nodules of garnet are generally seen on the rock surface in the hand-specimen. The detail petrography and reaction texture of these rocks were discussed by Dwivedi et al. (2019).

\subsection{Identification of monazite}

Monazite occurs as an accessory phase in the rocks of the study area. In the context of the identification of monazite grain under a petrological microscope, zircon creates some confusion with monazite. Monazite and zircon have some vital diagnostic features, and they could be distinguished by their characteristic. The zircon grains have distinct prismatic as well as 
Table 3. Representative electron microprobe analyses and structural formula of gedrite and cordierite.

\begin{tabular}{|c|c|c|c|c|c|c|c|c|}
\hline \multirow[b]{3}{*}{ Domain } & \multicolumn{4}{|c|}{ Gedrite } & \multicolumn{4}{|c|}{ Cordierite } \\
\hline & \multicolumn{2}{|c|}{ Sample no. R-91-97 } & \multicolumn{2}{|c|}{ Sample no. R-91-96 } & \multicolumn{2}{|c|}{ Sample no. R-91-97 } & \multicolumn{2}{|c|}{ Sample no. R-91-96 } \\
\hline & $174 / 1$ & $176 / 1$ & $86 / 1$ & $87 / 1$ & $24 / 1$ & $25 / 1$ & $120 / 1$ & $139 / 1$ \\
\hline $\mathrm{SiO}_{2}$ & 49.813 & 44.912 & 45.674 & 46.39 & 48.937 & 49.241 & 48.695 & 49.536 \\
\hline $\mathrm{TiO}_{2}$ & 0.017 & 0.256 & 0.222 & 0 & & & & \\
\hline $\mathrm{Al}_{2} \mathrm{O}_{3}$ & 6.39 & 11.83 & 11.523 & 10.24 & 30.111 & 30.457 & 30.222 & 30.381 \\
\hline $\mathrm{FeO}$ & 22.039 & 22.525 & 21.718 & 21.407 & 5.865 & 5.564 & 6.240 & 5.330 \\
\hline $\mathrm{MgO}$ & 16.986 & 14.979 & 15.569 & 16.19 & 10.204 & 10.024 & 9.926 & 10.168 \\
\hline $\mathrm{CaO}$ & 0.081 & 0.095 & 0.052 & 0.075 & & & & \\
\hline $\mathrm{Na}_{2} \mathrm{O}$ & 0.793 & 1.613 & 1.61 & 1.307 & 0.156 & 0.141 & 0.148 & 0.102 \\
\hline $\mathrm{BaO}$ & 0.305 & 0.339 & 0.204 & 0.238 & & & & \\
\hline $\mathrm{F}$ & 0.275 & 0.223 & 0.341 & 0.369 & & & & \\
\hline Total & 96.762 & 96.876 & 96.938 & 96.226 & 95.273 & 95.426 & 95.232 & 95.518 \\
\hline $\mathrm{Si}$ & 7.36 & 6.704 & 6.772 & 6.912 & 5.140 & 5.151 & 5.127 & 5.169 \\
\hline $\mathrm{Al}^{\mathrm{iv}}$ & 0.64 & 1.296 & 1.228 & 1.088 & 3.727 & 3.755 & 3.750 & 3.736 \\
\hline$\Sigma Z$ & 8 & 8 & 8 & 8 & 8.867 & 8.907 & 8.876 & 8.905 \\
\hline $\mathrm{Al}^{\mathrm{vi}}$ & 0.472 & 0.785 & 0.786 & 0.71 & & & & \\
\hline $\mathrm{Ti}$ & 0.002 & 0.029 & 0.025 & 0 & & & & \\
\hline $\mathrm{Fe}^{2+}$ & 2.723 & 2.812 & 2.693 & 2.667 & 0.548 & 0.487 & 0.549 & 0.465 \\
\hline $\mathrm{Mg}$ & 3.741 & 3.333 & 3.441 & 3.596 & 1.598 & 1.563 & 1.558 & 1.582 \\
\hline$\Sigma X$ & 6.938 & 6.959 & 6.945 & 6.974 & 2.146 & 2.050 & 2.107 & 2.047 \\
\hline $\mathrm{Ca}$ & 0.013 & 0.015 & 0.008 & 0.012 & & & & \\
\hline $\mathrm{Na}$ & 0.227 & 0.467 & 0.463 & 0.378 & 0.032 & 0.028 & 0.030 & 0.021 \\
\hline $\mathrm{Ba}$ & 0.017 & 0.02 & 0.012 & 0.014 & & & & \\
\hline$\Sigma Y$ & 0.258 & 0.502 & 0.483 & 0.403 & & & & \\
\hline $\mathrm{F}$ & 0.128 & 0.105 & 0.16 & 0.174 & & & & \\
\hline $\mathrm{OH}^{*}$ & 1.872 & 1.895 & 1.84 & 1.826 & & & & \\
\hline$X_{\mathrm{Mg}}$ & 0.58 & 0.54 & 0.56 & 0.57 & 0.745 & 0.762 & 0.739 & 0.773 \\
\hline
\end{tabular}

euhedral shape, but monazite grains are rarely rounded and anhedral in shape (Schaltegger et al. 1999). The pleochroic haloes formed by zircons were small, but monazite produced comparatively larger pleochroic haloes in flakes of biotite and cordierite, due to an abundance of Th, i.e., 3.14-7.20 wt\%. However, solely on optical properties, monazite and zircon grains cannot be easily distinguished. The backscattered electron (BSE) images were used to identify the monazite grains from the matrix and garnet.

\subsection{Textural interpretations of monazite}

The analyzed monazite grains occur as inclusion within porphyroblastic garnet, cordierite biotite and matrix (figure 3). Garnet shows the compositional variation from the core to the rim in which the core $\left(\mathrm{Py}_{29.5} \mathrm{Alm}_{69.5} \mathrm{Grs}_{0.7} \mathrm{Sps}_{0.3}\right)$ contains comparatively lower Alm and Sps and slightly higher in pyrope content in comparison with the rim $\left(\mathrm{Py}_{23.3} \mathrm{Alm}_{75.4^{-}}\right.$ $\mathrm{Grs}_{0.6} \mathrm{Sps}_{0.7}$ ) (figure 4). Monazite grain in the core of garnet (figure 3a) produced the older age in R-91-97, and many of the monazite grains embedded in the periphery area (figure $3 \mathrm{~b}$ ) generates the younger age in R-91-96. Garnet is rimmed by cordierite and shows the corona structure (figure 3a) which includes biotite and quartz as inclusion that leads to the formation of cordierite. Monazite grains are also present in the cordierite, biotite (figure $3 \mathrm{c}$ and $\mathrm{d}$ ), gedrite and matrix which provide a younger age.

\subsection{Microscopic characters and mineral chemistry}

Garnet occurs as coarse xenoblast and poikiloblast and contains gedrite, cordierite, biotite and quartz as 
Table 4. Representative electron microprobe analyses and structural formula of biotite.

\begin{tabular}{|c|c|c|c|c|c|}
\hline \multirow[b]{2}{*}{ Domain } & \multicolumn{2}{|c|}{ Sample no. R-91-97 } & \multicolumn{3}{|c|}{ Sample no. R-91-96 } \\
\hline & $159 / 1$ & $163 / 1$ & $52 / 1$ & $164 / 1$ & $158 / 1$ \\
\hline $\mathrm{SiO}_{2}$ & 39.067 & 38.778 & 38.377 & 37.884 & 38.573 \\
\hline $\mathrm{TiO}_{2}$ & 1.675 & 1.712 & 1.738 & 1.624 & 1.993 \\
\hline $\mathrm{Al}_{2} \mathrm{O}_{3}$ & 14.372 & 14.967 & 14.970 & 14.480 & 14.571 \\
\hline $\mathrm{FeO}$ & 13.072 & 12.707 & 11.619 & 12.407 & 12.043 \\
\hline $\mathrm{MgO}$ & 18.113 & 17.504 & 17.713 & 17.214 & 17.506 \\
\hline $\mathrm{CaO}$ & 0.028 & 0.000 & 0.000 & 0.001 & 0.004 \\
\hline $\mathrm{BaO}$ & 0.242 & 0.000 & 0.000 & 0.104 & 0.000 \\
\hline $\mathrm{Na}_{2} \mathrm{O}$ & 0.513 & 0.635 & 0.626 & 0.618 & 0.669 \\
\hline $\mathrm{K}_{2} \mathrm{O}$ & 8.019 & 8.984 & 8.796 & 9.160 & 8.969 \\
\hline $\mathrm{Cl}$ & 0.055 & 0.041 & 0.000 & 0.050 & 0.050 \\
\hline $\mathrm{F}$ & 1.696 & 2.112 & 1.775 & 2.052 & 2.122 \\
\hline Total & 96.853 & 97.441 & 95.766 & 95.595 & 96.498 \\
\hline $\mathrm{Si}$ & 5.738 & 5.699 & 5.698 & 5.694 & 5.715 \\
\hline $\mathrm{Al}^{\mathrm{iv}}$ & 2.262 & 2.301 & 2.302 & 2.306 & 2.285 \\
\hline$\Sigma Z$ & 8 & 8 & 8 & 8 & 8 \\
\hline $\mathrm{Al}^{\mathrm{vi}}$ & 0.226 & 0.292 & 0.318 & 0.259 & 0.259 \\
\hline $\mathrm{Ti}$ & 0.185 & 0.189 & 0.194 & 0.184 & 0.222 \\
\hline $\mathrm{Fe}^{2+}$ & 1.606 & 1.562 & 1.443 & 1.559 & 1.492 \\
\hline $\mathrm{Ba}$ & 0.014 & 0.000 & 0.000 & 0.006 & 0.000 \\
\hline $\mathrm{Mg}$ & 3.966 & 3.835 & 3.921 & 3.857 & 3.867 \\
\hline$\Sigma X$ & 5.997 & 5.878 & 5.875 & 5.865 & 5.840 \\
\hline $\mathrm{Ca}$ & 0.004 & 0.000 & 0.000 & 0.000 & 0.001 \\
\hline $\mathrm{Na}$ & 0.146 & 0.181 & 0.180 & 0.180 & 0.192 \\
\hline K & 1.503 & 1.684 & 1.666 & 1.756 & 1.695 \\
\hline$\sum Y$ & 1.653 & 1.865 & 1.846 & 1.936 & 1.888 \\
\hline $\mathrm{Cl}$ & 0.014 & 0.010 & 0.000 & 0.013 & 0.012 \\
\hline $\mathrm{F}$ & 0.788 & 0.982 & 0.833 & 0.975 & 0.994 \\
\hline$X_{\mathrm{Mg}}$ & 0.71 & 0.71 & 0.73 & 0.71 & 0.72 \\
\hline
\end{tabular}

$X_{\mathrm{Mg}}=\mathrm{Mg} /(\mathrm{Mg}+\mathrm{Fe})$. Structural formula calculated on 22 oxygen basis.

Table 5. Representative electron microprobe analyses and structural formula of ilmenite.

\begin{tabular}{lcccccc}
\hline & \multicolumn{2}{c}{ Sample no. R-91-97 } & & \multicolumn{3}{c}{ Sample no. R-91-96 } \\
\cline { 2 - 3 } \cline { 5 - 6 } Domain & $34 / 1$ & $35 / 1$ & & $36 / 1$ & $45 / 1$ & $46 / 1$ \\
\hline $\mathrm{TiO}_{2}$ & 51.496 & 51.342 & & 50.488 & 50.133 & 49.759 \\
$\mathrm{FeO}$ & 46.442 & 47.991 & & 47.860 & 47.856 & 48.121 \\
$\mathrm{MnO}$ & 0.221 & 0.312 & & 0.412 & 0.235 & 0.312 \\
$\mathrm{MgO}$ & 0.734 & 0.049 & & 0.135 & 0.106 & 0.061 \\
$\mathrm{SiO}_{2}$ & 0.132 & 0.025 & & 0.136 & 0.019 & 0.1 \\
Total & $\mathbf{9 9 . 0 2 5}$ & $\mathbf{9 9 . 7 1 9}$ & & $\mathbf{9 9 . 0 3 0}$ & $\mathbf{9 8 . 3 4 8}$ & $\mathbf{9 8 . 3 5 3}$ \\
$\mathrm{Ti}^{3+}$ & 0.886 & 0.891 & & 0.864 & 0.873 & 0.846 \\
$\mathrm{Fe}^{3+}$ & 0.090 & 0.087 & & 0.065 & 0.087 & 0.069 \\
$\mathrm{Fe}$ & 0.924 & 0.935 & & 0.986 & 0.946 & 0.965 \\
$\mathrm{Mn}$ & 0.012 & 0.017 & & 0.024 & 0.004 & 0.018 \\
$\mathrm{Mg}$ & 0.026 & 0.001 & & 0.012 & 0.004 & 0.001 \\
$\mathrm{Si}$ & 0.007 & 0.001 & & 0.011 & 0.001 & 0.008 \\
Total & $\mathbf{1 . 9 4 5}$ & $\mathbf{1 . 9 3 2}$ & & $\mathbf{1 . 9 6 2}$ & $\mathbf{1 . 9 1 5}$ & $\mathbf{1 . 9 0 7}$ \\
\hline
\end{tabular}

Structural formula calculated on three oxygen basis. an inclusion with some other heavy minerals i.e., monazite, ilmenite, magnetite, zircon, etc. Garnet grains are highly fractured and partially rimmed by gedrite and cordierite. The small flake of biotite occurs as inclusion along with quartz within the garnet (figure 2c). Garnet shows solid solution dominantly between almandine (65.4-74.3 mol\%) and pyrope (24.3-32.8 mol\%) with minor amounts of grossular (0.7-1.2 mol\%) and spessartine (0.6-0.7 mol\%). The $X_{\mathrm{Mg}}$ of garnet lies between 0.25 and 0.27 (table 2).

The BSE image shows the inclusion of biotite and quartz in garnet (figure $4 \mathrm{a}$ ), and the elemental X-ray map of garnet reveals the enrichment of $\mathrm{Fe}$ and $\mathrm{Mg}$ elements (figure $4 \mathrm{~b}$ and $\mathrm{c}$ ) and depletion of $\mathrm{Mn}$ and $\mathrm{Ca}$ elements (figure $4 \mathrm{~d}$ and e). Garnet shows the dominance of the almandine in which $X_{\mathrm{Alm}}$ varies from 0.68 to 0.77 . The length of the porphyroblastic garnet is $890 \mu \mathrm{m}$, and the rim-core-rim distribution of almandine and pyrope garnet is graphically represented (figure 4f). Here almandine shows a high-composition peak at the rim and a lower one at the core area. Pyrope represents a higher occurrence at the core and lower occurrence at the rim portion $\left(X_{\mathrm{Py}}=0.22-0.34\right)$. The $\mathrm{Fe}$ content of garnet increases and the $\mathrm{Mg}$ content decreases at the rim of the garnet porphyroblast due to locally resorbed by gedrite + cordierite minerals or by retrogressive biotite. This situation indicates the lowering of the pressure and the temperature at the rim of garnet porphyroblast as compared to the core portion.

Hypersthene is idioblastic to xenoblastic in nature and varies from medium to coarse (figure 2c). It shows strong pleochroism from pink to bluish-green in colour. Hypersthene is partially rimmed by garnet and gedrite. The $X_{\mathrm{Mg}}$ of hypersthene ranges between 0.52 and 0.58 (table 2).

Xenoblast and coarse aggregates of cordierite wrap the garnet and gedrite (figure 2d). Corroded cordierite is completely rimmed by garnet which provides evidence of the prograde metamorphic condition. Cordierite shows some alteration along the grain boundaries and the fractured zone. Cordierite includes magnetite, quartz, monazite, etc. as inclusions. Cordierite compositions are magnesian, and $X_{\mathrm{Mg}}$ ranges from 0.74 to 0.77 (table 3).

Gedrite is coarse-grained and has idioblastic prisms in thin sections. It is commonly associated with biotite to define foliation in rocks (figure $2 \mathrm{~d}$ ). 


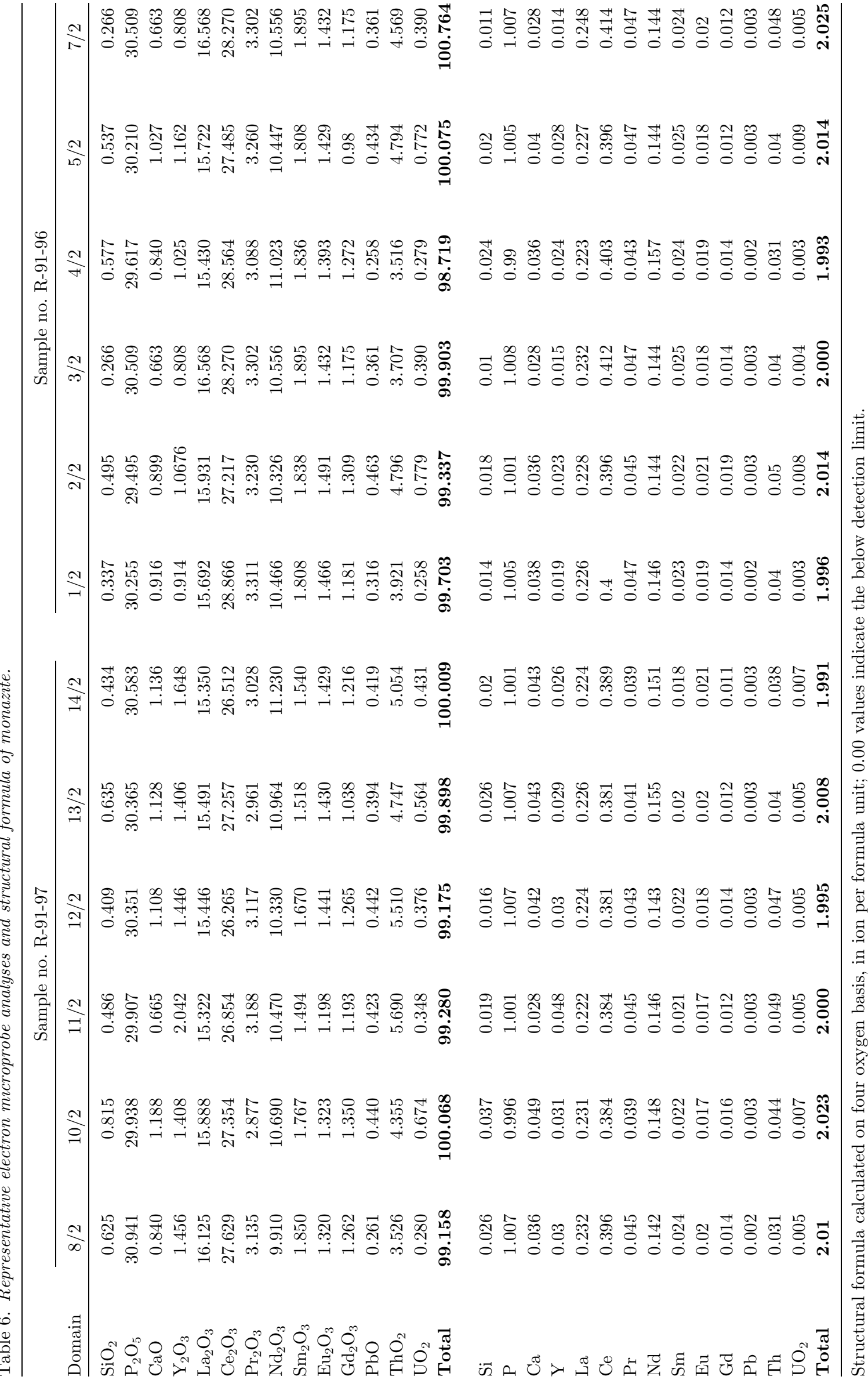



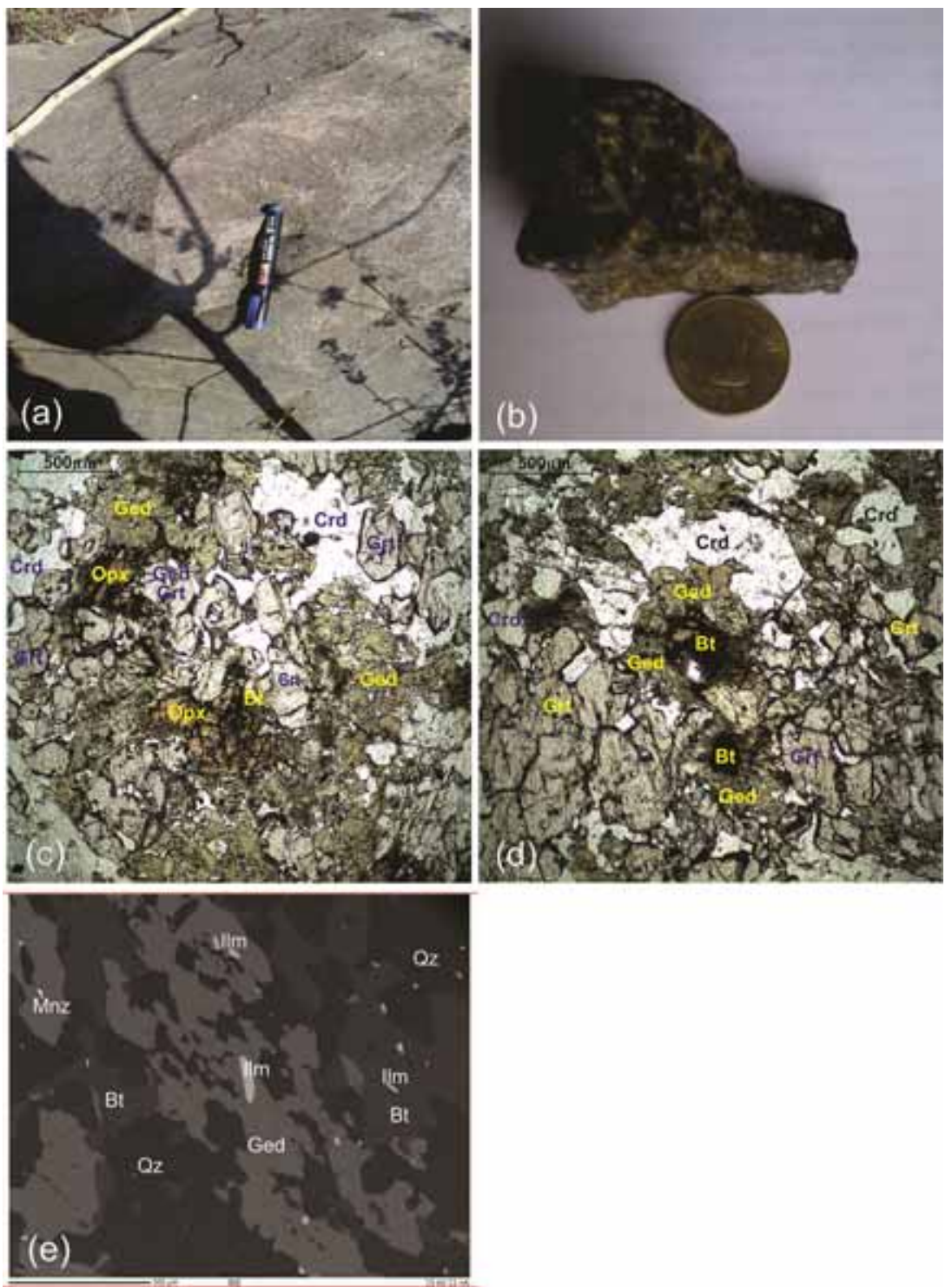

Figure 2. (a) Field photograph of the garnet-gedrite-cordierite-biotite gneiss; (b) representative hand-specimen of the garnet-orthopyroxene-gedrite-cordierite gneiss; (c) photomicrographs showing the gedrite rimmed by garnet and cordierite, where orthopyroxene coexists with garnet; (d) photomicrographs showing the small grain of brown biotite present as inclusion in gedrite and gedrites are surrounded by a huge mass of garnet and cordierite; (e) BSE image shows some accessory minerals, i.e., monazite and ilmenite with other minerals like gedrite, biotite and quartz.

It contains inclusions of cordierite, biotite, quartz, etc. It shows parallel extinction and pleochroism in which the colour varies from yellowish green to greenish brown. Gedrite contains a trail of biotite as inclusion which suggests the appearance of gedrite in the rock due to the breakdown of biotite + quartz. Gedrite consists of $\mathrm{Al}^{\mathrm{IV}}$ and $\mathrm{Al}^{\mathrm{VI}}$ components in sufficient quantities $0.64-1.29$ and $0.47-0.78 \mathrm{pfu}$, respectively, and the $X_{\mathrm{Mg}}$ ranges from 0.54 to 0.58 (table 3 ).

Biotite occurs in the form of small flakes and as individual laths within the hypersthene (figure 2c). It occurs as inclusion in gedrite and partially wrapped by cordierite (figure 2d). The $\mathrm{TiO}_{2}$ content of biotite varies from 1.62 to $1.99 \mathrm{wt} \%$, and its compositions are magnesian with the $X_{\mathrm{Mg}}$ ranges from 0.71 to 0.73 (table 4 ).

Ilmenite occurs as elongated and prismatic grains, which are very fine-grained and present as inclusion in gedrite, biotite, garnet and other mineral grains (figure 2e). Compositionally, they are magnesian-mangaon ilmenites (MgO: 0.049-0.734 wt\% and MnO: 0.221-0.412 wt\%) (table 5).

Monazite grains occur as accessory minerals in the matrix and are ubiquitous in garnet-hypersthene-gedrite-cordierite gneisses as well as 

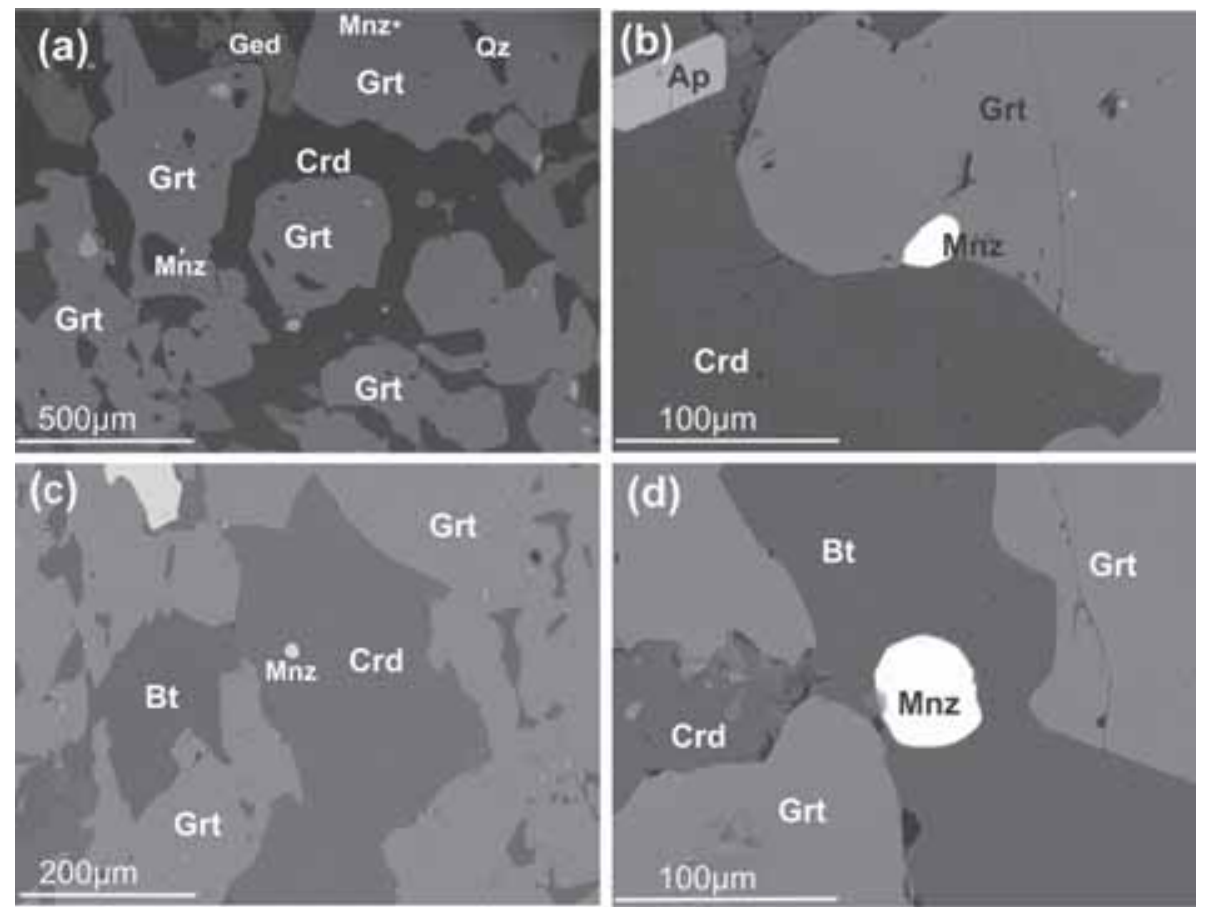

Figure 3. BSE images showing the microstructural and textural settings of monazite occurrences in the granulitic gneiss of Daltonganj. (a) Monazite occurring as inclusion within porphyroblastic garnet in R-91-97. (b) Monazite grain occurring as inclusion within the periphery area of garnet in R-91-97. (c) Monazite present as inclusion in the cordierite, Crd are later surrounded by garnet in R-91-96. (d) Monazite occurring as inclusion within biotite in R-91-96.

garnet-gedrite-cordierite-biotite gneisses; large grains of monazite (60-80 micron) are commonly found in high-grade metamorphic rocks (Montel et al. 1996). The monazite grains contain 3.14-7.20 wt\% of thorium oxide $\left(\mathrm{ThO}_{2}\right), 0.28-1.52 \mathrm{wt} \%$ of uranium oxide $\left(\mathrm{UO}_{2}\right)$ and $0.26-0.44 \mathrm{wt} \%$ of lead oxide (PbO) in the sample R-91-97. The sample R-91-96 contains 3.53-6.18 wt\% of $\mathrm{ThO}_{2}$, $0.26-1.45 \mathrm{wt} \%$ of $\mathrm{UO}_{2}$ and $0.26-0.46 \mathrm{wt} \%$ of $(\mathrm{PbO})$. The normalised cations based on the four oxygen basis are presented in table 6 and supplementary table 1 .

\section{Monazite geochronology}

\subsection{Sample description and $U-T h-P b$ systematics}

R-91-97 and R-91-96 samples have been chosen for microprobe dating after systematic EPMA-BSE imaging. Monazite grains are of diameter $(70-80 \mu \mathrm{m})$ and compositionally homogeneous (figure $5 \mathrm{a}-\mathrm{h}$ ). The monazite grains show the homogeneous compositional domain which is demarcated by the BSE image and $\mathrm{X}$-ray elemental mapping. The X-ray elemental maps of some selective monazite grains P43 of R-91-97 and P46 of R-91-96 are shown in figure 5(a-h). Both P43 and P46 monazite grains occur as inclusions in the garnet porphyroblast and are relatively poor in yttrium (Y) elemental composition at the outer rim margin in comparison with the core (figure $5 \mathrm{~d}$ and $\mathrm{h}$ ). The yttrium $(\mathrm{Y})$ partitioning in the monazite is directly linked to the growth or consumption by the peritectic garnet (Spear and Pyle 2010; Bhowmik et al. 2014). But, U and Th X-ray elemental maps are showing homogeneous composition in both the grains (figure $5 \mathrm{~b}, \mathrm{c}, \mathrm{f}$ and $\mathrm{g}$ ). $\mathrm{U}$ and $\mathrm{Th}$ with $\mathrm{Pb}$ were found to occur together in both huttonite and brabantite types of substitution. Monazite shows the compositional variation between $\mathrm{Th}(+\mathrm{Ca}$ and $\mathrm{Si})$ and $\mathrm{Y}(+\mathrm{HREE})$ and it reflects the different substitutions: brabantite substitution $\left(\mathrm{Th}^{4+}+\mathrm{Ca}^{2+}=2 \mathrm{REE}^{3+}\right.$; Rose 1980) and huttonite substitution $\left(\mathrm{Th}^{4+}+\mathrm{Si}^{4+}=\mathrm{LREE}^{3+}+\right.$ $\mathrm{P}^{5+}$; Pabst and Hutton 1951). The variation of the brabantite vs. huttonite exchange operation is presented in the plot of $\mathrm{Th}+\mathrm{U}+\mathrm{Si}$ vs. $\mathrm{REE}+\mathrm{Y}+\mathrm{P}$ (figure 6). All monazite grains contained negligible $\mathrm{SiO}_{2}$. However, they contain sufficient amounts of $\mathrm{Ca}$ which quantify the brabantite ( $\mathrm{Th} / \mathrm{U}+\mathrm{Ca} \leftrightarrow 2 \mathrm{REE})$ substitution. Here, the brabantite substitution is dominant in monazites. 

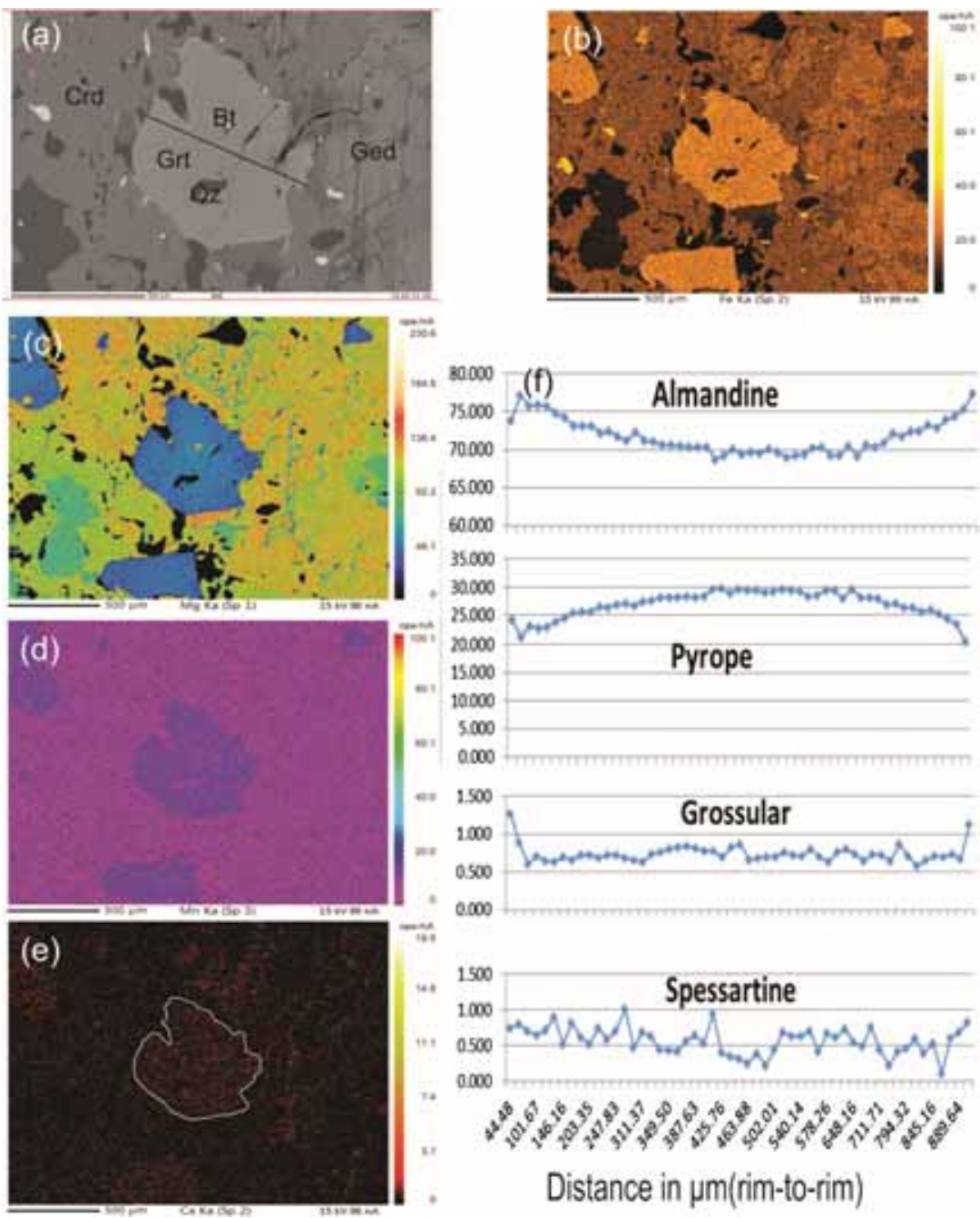

Figure 4. (a) BSE image of garnet porphyroblast with inclusions of biotite and quartz; (b-e) these images represent the X-ray mapping of $\mathrm{Fe}, \mathrm{Mg}, \mathrm{Mn}$ and $\mathrm{Ca}$ in garnet porphyroblast; (f) $X_{\mathrm{Alm}}, X_{\mathrm{Py}}, X_{\mathrm{Grs}}$ and $X_{\mathrm{Sps}}$ variation along the garnet porphyroblast from rim to rim.

\subsection{Electron microprobe dating}

Electron microprobe dating can be used as an efficient investigation tool for finding the age of metamorphism and deformational history (Williams et al. 1999). Here, EPMA monazite geochronology was conducted to find out the age, and to establish the evolutionary history of the granulite of Daltonganj.

Monazite grains vary in shape from anhedral to subhedral or rounded and size from the smaller grain $(10-30 \mu \mathrm{m})$ to larger grain $(60-80 \mu \mathrm{m})$. It occurs as inclusion within garnet and the matrix. Estimation of age and uncertainties are compared from different monazite grains, and monazite growth events were interpreted which recorded from the Daltonganj area of CGGC. A total of 39 EPMA ages were obtained from 39 monazite mineral grains of the two different granulite samples. The $\mathrm{Th}-\mathrm{U}-\mathrm{Pb}$ values from the different monazite grains of R-91-97 and R-91-96 samples are given in table 7. EPMA dating generates two age domains, and the calculated monazite ages range from $1348 \pm 47$ to $1482 \pm 49 \mathrm{Ma}$ and $896 \pm 49$ to $1050 \pm 63$ Ma in R-91-97, and vary from $1322 \pm 64$ to $1494 \pm 65 \mathrm{Ma}$ and $926 \pm 58$ to $1019 \pm 59 \mathrm{Ma}$ in R-91-96 (figure 7). The weighted average age distribution and probability density plot was obtained by using the ISOPLOT program (Ludwig 2011) which is depicted in figure $8 \mathrm{a}-\mathrm{h}$. The analysis of sample R-91-97 produced age population at $1424 \pm 64 \mathrm{Ma}$ (figure $8 \mathrm{a}$ and b) and $972 \pm 28 \mathrm{Ma}$, with $95 \%$ confidence (figure $8 \mathrm{c}$ and d). The sample R-91-96 yielded age population at $1390 \pm 56 \mathrm{Ma}$ (figure 8e and f) and $962 \pm 159 \mathrm{Ma}$, with $95 \%$ confidence (figure $8 \mathrm{~g}$ and $\mathrm{h}$ ). The electron microprobe dating of monazite grains has generated the two-age domain from both rocks, i.e., garnet-hypersthene-gedrite-cordierite gneiss and 

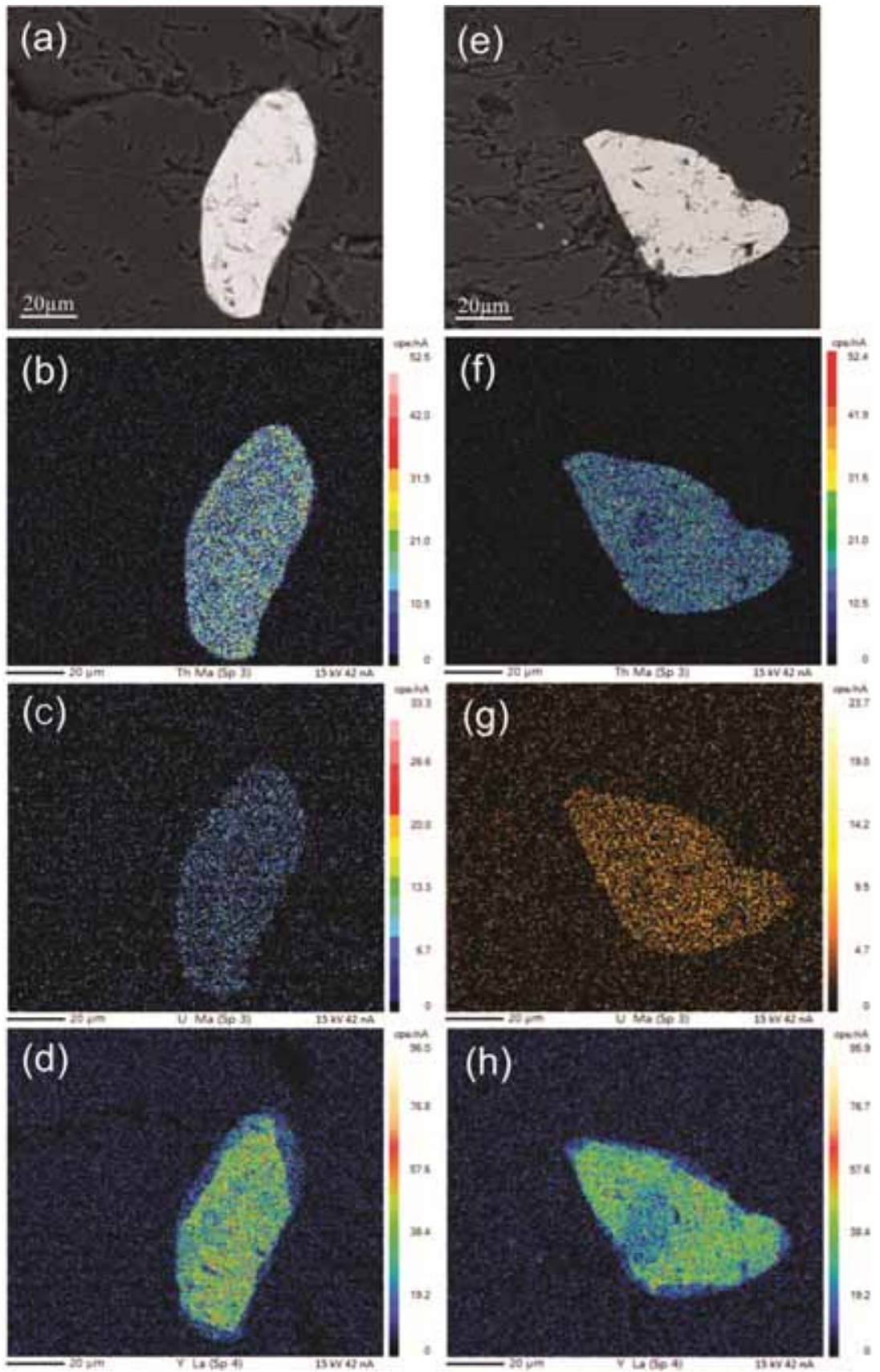

Figure 5. Grain-P43 of the R-91-97 sample, (a) BSE image. (b) and (c) X-ray elemental maps documenting the homogeneous pattern of Th and $\mathrm{U}$ elements in monazite. (d) X-ray map shows the zoning pattern at the outer part in monazite; wherein grain-P46 of the R-91-96 sample, (e) BSE image, (f) and (g) X-ray elemental maps documenting the homogeneous pattern of Th and $\mathrm{U}$ elements in the monazite. (h) X-ray map shows the zoning pattern at the outer part as well as the core of monazite.

garnet-gedrite-cordierite-biotite gneiss, which lies around the Mesoproterozoic and Grenville orogeny age.

\section{6. $P-T$ condition of metamorphism}

The $P-T$ conditions were estimated from the heterogeneous compositions of garnet and cordierite from garnet-hypersthene-gedrite-cordierite gneiss. The garnet-cordierite $\mathrm{Mg}-\mathrm{Fe}$ exchange geothermometers and garnet-cordierite-sillimanite-quartz geobarometers were used to estimate the $P-T$ conditions and their results are summarised in tables 8 and 9. The maximum and minimum temperatures obtained at 7 kbar pressure were $788^{\circ}$ and $656^{\circ} \mathrm{C}$, respectively. At $700^{\circ} \mathrm{C}$, the corresponding pressure varies from 4.80 to 7.34 kbar. By using the THERMOCALC v-3.21 thermodynamic modelling program by Holland and 


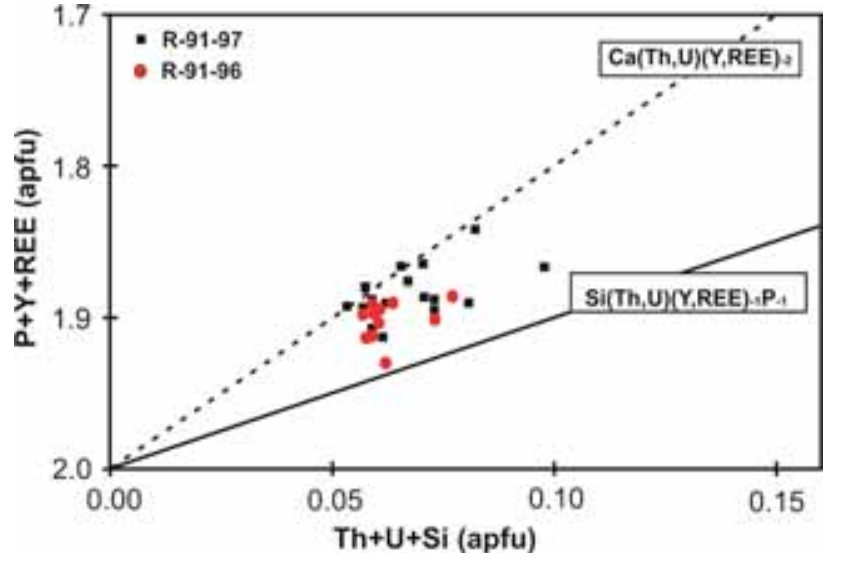

Figure 6. The bivariate plot shows the variation in the composition of monazite of two different granulite samples from Daltonganj (CGGC). Both rock types are enriched in the brabantite substitution vector as marked in the diagram.

Powell (1998), the $P-T_{\text {avg }}$ was estimated for garnet-hypersthene-cordierite-biotite gneiss, the estimated average temperature and pressure $\left(P T_{\text {avg }}\right)$ were $792^{\circ} \mathrm{C}$ and $7.35 \mathrm{kbar}$. The calculated pressure and temperature have corresponded to initial heating and compression until achieving a peak metamorphic condition, i.e., prograde metamorphism until the peak.

\section{Discussion}

\subsection{The timing of metamorphic events}

The CGGC has a multiplex metamorphic history, based on pre-existing geological information; the CGGC has been divided into four phases of metamorphic events $\left(\mathrm{M}_{1}-\mathrm{M}_{4}\right)$. The $\mathrm{M}_{1}$ metamorphic event is recorded at $\sim 1870$ Ma from granulite enclaves emplaced in felsic gneiss; furthermore, the $\mathrm{M}_{2}$ metamorphic event was dated between 1628 and $1270 \mathrm{Ma}$, where felsic magma intrusion occurred and further metamorphosed to form the migmatitic felsic gneiss. The $\mathrm{M}_{3}$ phase is a high-grade metamorphic event that occurred during 1200-930 Ma, followed by the $\mathrm{M}_{4}$ event (870-780 Ma) with the emplacement of the mafic dyke (Sanyal and Sengupta 2012 and references therein). The geochronological studies of various researchers from different localities of the CGGC, metamorphic phases $\left(\mathrm{M}_{1}-\mathrm{M}_{4}\right)$, dating techniques and nature of rocks are compiled in table 1 .

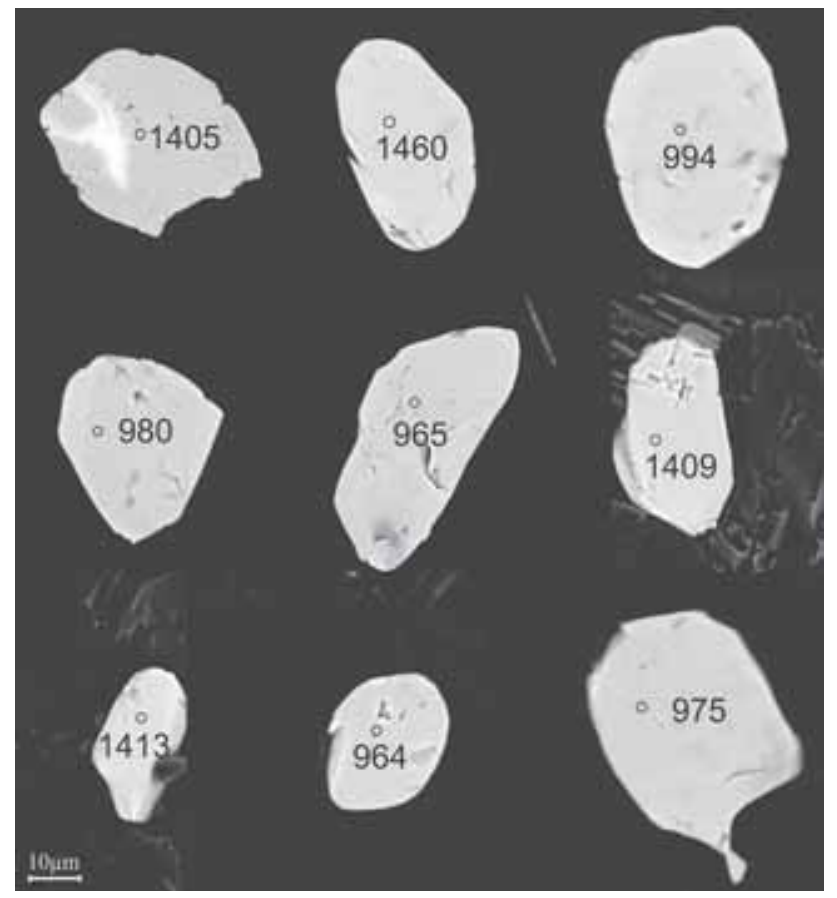

Figure 7. Represents the backscattered images (BSE-SEM) of different monazite grains from two rock samples.

The $P-T$ conditions during the $\mathrm{M}_{1}$ metamorphic stage of the granulite facies rocks are difficult to derive due to their complex history of successive metamorphic events. Prograde granulite facies metamorphism was reported in the enclave suite $\left(750-850^{\circ} \mathrm{C} / 4-6 \mathrm{kbar}\right)$, and this event was reported at $>1500$ Ma age by Maji et al. (2008). The $P-T$ condition and the petrographic reaction texture relations are preserved within the rocks of the CGGC, which suggest the two prominent metamorphic events $M_{2}$ and $M_{3}$ that correspond to Mesoproterozoic and Grenvillian orogeny age (Sanyal and Sengupta 2012). These events represent the two different episodes of progressive metamorphism, which is separated by retrogressive metamorphic events (Maji et al. 2008), but the representative age is not distinguished. $\mathrm{U}-\mathrm{Pb}$ zircon dating reveals that the age of intrusive A-type felsic magma (protolith of charnockite) is at $1447+11 \mathrm{Ma}$ (Mukherjee et al. 2017), also during 1470-1450 Ma age, the emplacement of ferroan granitoids was reported in the north-eastern part of the CGGC (Mukherjee et al. 2018). A-type granitoid magmatism and fragmentation of the Columbia supercontinent are recorded during the Mesoproterozoic era (Hoffman 1989; Frost and Frost 2011). The monazite age $(1424 \pm 64 \mathrm{Ma})$ is revealed as the oldest age of the garnet-hypersthene-gedrite-cordierite 
Table 7. EPMA dating age of monazite crystals of granulites from the Daltonganj (Palamau) area.

\begin{tabular}{|c|c|c|c|c|c|}
\hline $\mathrm{UO}_{2}$ & $\mathrm{ThO}_{2}$ & $\mathrm{PbO}$ & $\mathrm{Y}_{2} \mathrm{O}_{3}$ & Age (Ma) & Age err \\
\hline \multicolumn{6}{|c|}{ Sample no. R-91-97 } \\
\hline 0.280 & 3.526 & 0.261 & 0.351 & 1353 & 65 \\
\hline 0.674 & 4.355 & 0.440 & 1.408 & 1482 & 49 \\
\hline 0.348 & 5.690 & 0.423 & 2.042 & 1405 & 48 \\
\hline 0.376 & 5.510 & 0.442 & 1.446 & 1481 & 51 \\
\hline 0.564 & 4.747 & 0.394 & 1.406 & 1348 & 47 \\
\hline 0.431 & 5.05 & 0.419 & 1.648 & 1460 & 51 \\
\hline \multicolumn{6}{|c|}{ Weighted mean age $1424 \pm 64 \mathrm{Ma}(n=6, \mathrm{MSWD}=1.4$, probability $=0.21)$} \\
\hline 1.215 & 6.181 & 0.442 & 1.729 & 965 & 55 \\
\hline 1.380 & 5.308 & 0.422 & 1.741 & 917 & 43 \\
\hline 1.115 & 5.591 & 0.390 & 2.034 & 994 & 54 \\
\hline 0.917 & 5.391 & 0.335 & 1.191 & 980 & 57 \\
\hline 1.049 & 5.076 & 0.371 & 2.485 & 995 & 46 \\
\hline 1.415 & 5.297 & 0.416 & 1.065 & 956 & 46 \\
\hline 0.939 & 6.053 & 0.346 & 1.848 & 912 & 51 \\
\hline 0.987 & 3.136 & 0.387 & 1.587 & 945 & 55 \\
\hline 1.184 & 3.416 & 0.387 & 0.993 & 1029 & 61 \\
\hline 0.904 & 5.406 & 0.385 & 0.565 & 1050 & 63 \\
\hline 1.240 & 7.204 & 0.432 & 0.401 & 896 & 49 \\
\hline 1.518 & 5.197 & 0.444 & 2.088 & 994 & 53 \\
\hline 0.960 & 4.834 & 0.294 & 2.096 & 1049 & 48 \\
\hline 1.009 & 3.372 & 0.276 & 1.890 & 985 & 60 \\
\hline
\end{tabular}

Weighted mean age $972 \pm 28 \mathrm{Ma}(n=14, \mathrm{MSWD}=0.55$, probability $=0.47)$.

Sample no. R-91-96

$\begin{array}{llllll}0.258 & 3.921 & 0.316 & 0.914 & 1494 & 65 \\ 0.779 & 4.796 & 0.463 & 1.068 & 1409 & 44 \\ 0.279 & 3.516 & 0.258 & 0.402 & 1322 & 64 \\ 0.772 & 4.794 & 0.434 & 1.162 & 1331 & 43 \\ 0.591 & 6.072 & 0.459 & 0.599 & 1400 & 41 \\ 0.530 & 4.584 & 0.397 & 1.463 & 1413 & 50\end{array}$

Weighted mean age $1390 \pm 56 \mathrm{Ma}(n=6, \mathrm{MSWD}=1.2$, probability $=0.30)$.

$\begin{array}{llllrl}1.448 & 4.568 & 0.413 & 2.370 & 964 & 50 \\ 1.215 & 6.181 & 0.442 & 1.729 & 945 & 52 \\ 1.050 & 5.57 & 0.387 & 2.243 & 984 & 64 \\ 0.971 & 5.658 & 0.337 & 2.383 & 958 & 62 \\ 0.591 & 6.072 & 0.459 & 0.599 & 1019 & 59 \\ 1.034 & 5.098 & 0.365 & 2.124 & 983 & 61 \\ 1.121 & 5.500 & 0.398 & 2.219 & 926 & 58 \\ 1.144 & 5.228 & 0.383 & 2.021 & 933 & 54 \\ 0.883 & 5.802 & 0.266 & 1.170 & 975 & 51 \\ 1.415 & 5.297 & 0.416 & 1.065 & 938 & 52 \\ 0.591 & 6.072 & 0.459 & 0.599 & 990 & 60 \\ 1.144 & 5.577 & 0.437 & 2.329 & 965 & 51 \\ 1.034 & 5.098 & 0.365 & 2.124 & 938 & 58\end{array}$

Weighted mean age $962 \pm 15 \mathrm{Ma}(n=13, \mathrm{MSWD}=0.88$, probability $=0.57)$.

gneiss; it is signified as the age of the gneissic protolith. The EPMA monazite ages 972 and 962 Ma (Grenville Orogeny) represent the high-grade granulite facies event, which is recorded in the
Daltonganj. Petrographical features show that recrystallisation of the amphibole-rich magmatic rock to garnet-hypersthene-bearing gneiss by the following reaction during the $\mathrm{M}_{3}$ event: 

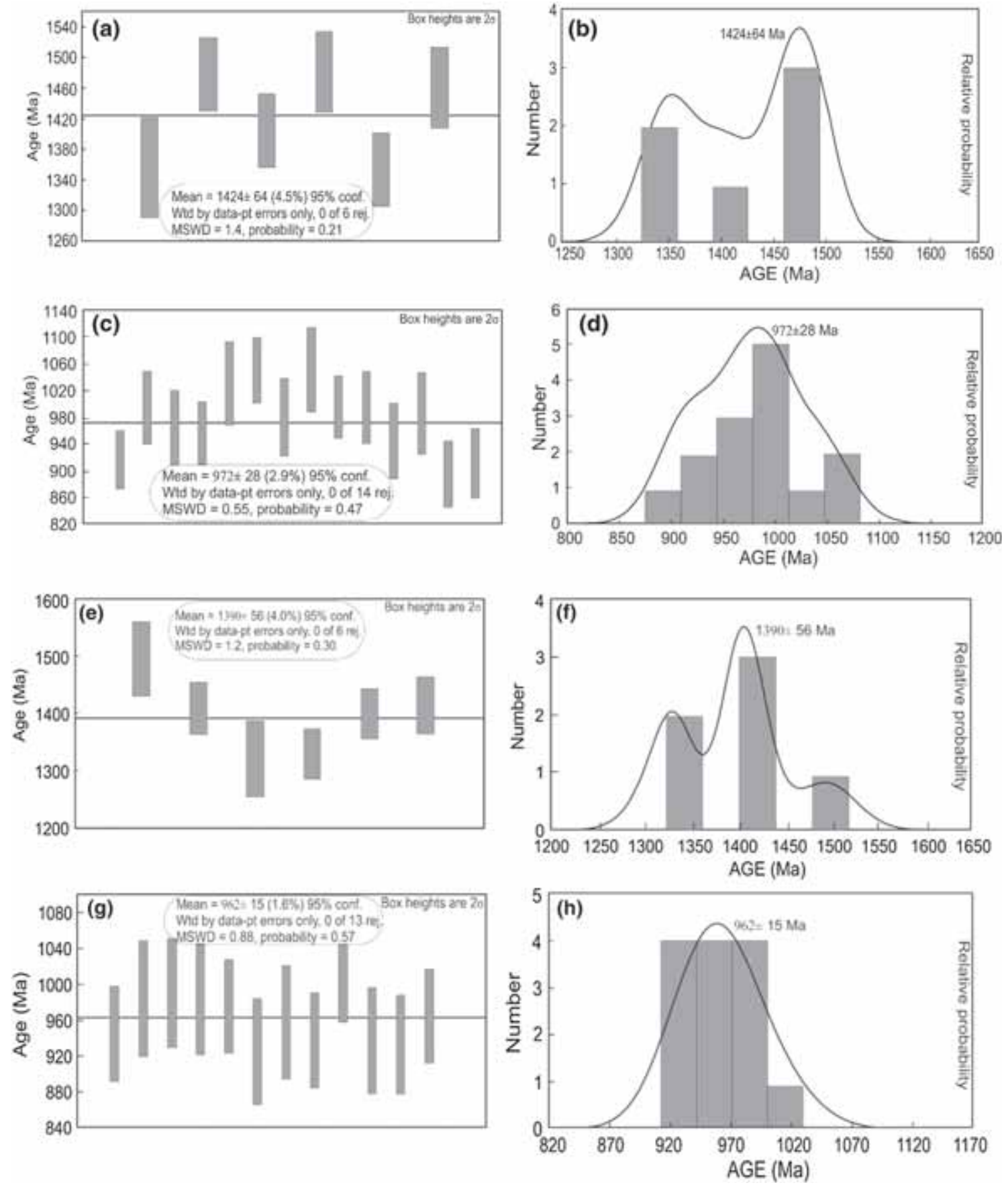

Figure 8. (a) and (c) Weighted-average ages (b) and (d) probability-density ages of two distinct age domains from the R-91-97 rock sample and (e) and (g) weighted-average ages and (f) and (h) probability-density ages of two distinct age domains from the R-91-96 rock sample with $2 \sigma$ uncertainty, different numbers of point analysis and MSWD (mean square of weighted deviates) for monazite from the Daltonganj area of the CGGC, plotted with the ISOPLOT program (Ludwig 2011).

Gedrite + quartz $=$ Garnet + hypersthene

$$
+ \text { cordierite }+ \text { albite }+\mathrm{H}_{2} \mathrm{O} \text {. }
$$

The appearance of the hypersthene indicates that the low $P-T$ condition has changed into a high $P-T$ condition of granulite facies. The $P-T$ condition and reaction texture are interpreted from the mineral assemblage, which shows that gedrite and quartz are consumed to produce the garnet + hypersthene + cordierite mineral phases through the prograde metamorphism. Similar $P-T$ condition and Grenvillian orogenic age (975 $\pm 67 \mathrm{Ma}$ ) were obtained by Chatterjee and Ghose (2011) from Chianki village of the Daltonganj area present in the north-west of the CGGC. 
Table 8. Pressure and temperature estimates of the garnet-hypersthene-gedrite-cordierite-gneiss of the study area through conventional geothermobarometers and internally consistent data sets.

Estimate of geothermometers (temperature in ${ }^{\circ} \mathrm{C}$ )

$$
\text { at } 7 \mathrm{kbar}
$$

Garnet-cordierite geothermometer

1. Thompson (1976)

2. Holdaway and Lee (1977)

3. Wells (1979)

4. Perchuk et al. (1985)

5. Perchuk (1991)

6. Bhattacharya et al. (1988)

7. Aranovich and Podlesskii (1989)

8. Nichols et al. (1992)

9. Dwivedi et al. (1998)

10. Average
Estimate of geobarometers (pressure in kbar) at $700^{\circ} \mathrm{C}$

Garnet-cordierite-sillimanite-quartz geobarometer

$\begin{array}{lllll}726 & & & P-\mathrm{Mg} & P-\mathrm{Fe} \\ 699 & \text { 1. } & \text { Thompson (1976) } & 5.91 & 6.33 \\ 788 & \text { 2. } & \text { Wells (1979) } & 7.34 & 6.38 \\ 706 & \text { 3. } & \text { Nichols et al. (1992) } & 4.85 & 5.72 \\ 703 & \text { 4. } & \text { Perchuck et al. (1985) } & 6.57 & \\ 737 & \text { 5. } & \text { Wells and Richardson (1980) } & 6.67 \\ 711 & \text { 6. } & \text { Lal (1991) } & \\ 656 & \text { 7. } & \text { Aranovich and Podlesskii (1983, 1989) } & 6.87 & \\ 746 & 8 . & \text { Average } & 6.06 \pm 0.90 & 6.28 \pm 0.35 \\ 719 \pm 30 & & & \end{array}$

Table 9. Result of internally consistent geothermobarometry with THERMOCALC v-3.21 (Holland and Powell 1998).

(Cordierite present reaction)

Reactions used to calculate average temperature $\left(T_{\mathrm{av}}\right)\left(\right.$ for $\left.x\left(\mathrm{H}_{2} \mathrm{O}\right)=1.0\right)$

\begin{tabular}{lccc}
\hline Independent set of reactions & $T\left({ }^{\circ} \mathrm{C}\right)$ & $\mathrm{Sd}(T)$ & $\ln K$ \\
\hline 1) $2 \mathrm{mgts}+3 \mathrm{q}=\mathrm{crd}$ & 604 & 1166 & 7.671 \\
2) $2 \mathrm{py}+3 \mathrm{fs}=2 \mathrm{alm}+$ 3en & 532 & 455 & 6.990 \\
$3)$ py + 3fcrd $=$ 2alm $+3 \mathrm{crd}$ & 641 & 215 & 12.639 \\
4) 3fs + 3mgts $=$ py $+2 \mathrm{alm}$ & 632 & 938 & 11.143 \\
& $T_{\mathrm{av}}$ & $\mathrm{Sd}$ & fit \\
Average temperature $\left({ }^{\circ} \mathrm{C}\right)$ & 602 & 47 & 1.01 \\
\hline
\end{tabular}

Reactions used to calculate average $\left(P_{\text {av }}\right)$ pressure (for $x\left(\mathrm{H}_{2} \mathrm{O}\right)=1.0$ )

5) $2 \mathrm{py}+4 \mathrm{alm}+9 \mathrm{q}=6 \mathrm{fs}+3 \mathrm{crd}$

\begin{tabular}{lcr}
$P(\mathrm{kbar})$ & $\mathrm{Sd}(P)$ & $\ln K$ \\
\hline 5.5 & 0.94 & 0.727 \\
5.9 & 1.11 & -2.088 \\
$P_{\mathrm{av}}$ & $\mathrm{Sd}$ & $\mathrm{fit}$ \\
5.56 & 0.93 & 0.61 \\
$601^{\circ} \mathrm{C} / 5.6 \mathrm{kbar}$ & & \\
\hline
\end{tabular}

Average pressure (kbar)

Single end member diagnostic information of $\left(P-T_{\mathrm{av}}\right)$

(Cordierite absent reaction)

Reactions used to calculate average temperature $\left(T_{\mathrm{av}}\right)\left(\right.$ for $\left.x\left(\mathrm{H}_{2} \mathrm{O}\right)=1.0\right)$

\begin{tabular}{lccc}
\hline Independent set of reactions & $T\left({ }^{\circ} \mathrm{C}\right)$ & $\mathrm{Sd}(T)$ & $\ln K$ \\
\hline 1) fs + fctd $=$ alm $+\mathrm{H}_{2} \mathrm{O}$ & 678 & 47 & 1.456 \\
$2)$ py $+3 \mathrm{fs}=2 \mathrm{alm}+3 \mathrm{en}$ & 797 & 412 & 4.940 \\
$3)$ py + east $=2 \mathrm{mgts}+$ phl & 782 & 427 & -2.452 \\
& $T_{\mathrm{av}}$ & $\mathrm{Sd}$ & $\mathrm{fit}$ \\
Average temperature $\left({ }^{\circ} \mathrm{C}\right)$ & 752 & 25 & 0.81
\end{tabular}

Reactions used to calculate average $\left(P_{\mathrm{av}}\right)$

pressure (for $x\left(\mathrm{H}_{2} \mathrm{O}\right)=1.0$ )

4) $\mathrm{alm}+2 \mathrm{en}+$ east $=2 \mathrm{py}+\mathrm{ann}$

$P(\mathrm{kbar})$

$5) \mathrm{en}+3 \mathrm{fs}+2 \mathrm{east}=2 \mathrm{alm}+2 \mathrm{phl}$

7.6

7.2

$P_{\text {av }}$

7.40

$792^{\circ} \mathrm{C} / 7.35 \mathrm{kbar}$

\begin{tabular}{lc} 
Sd $(P)$ & $\ln K$ \\
\hline 12.54 & -4.160 \\
4.21 & 5.234 \\
Sd & fit \\
0.90 & 0.5
\end{tabular}

Single-end member diagnostic information of $\left(P-T_{\mathrm{av}}\right)$

Note: Mineral abbreviations are alm = almandine, $\mathrm{ann}=$ annite, $\mathrm{crd}=$ cordierite, $\mathrm{en}=$ enstatite, east $=$ eastonite, fcrd $=$ ferro-cordierite, $\mathrm{fs}=$ ferrosillite, mgts $=$ Mg-Tschermak pyroxene, $\mathrm{q}=$ quartz, phl = phlogopite, py $=$ pyrope and $\mathrm{H}_{2} \mathrm{O}=$ water fluid. 


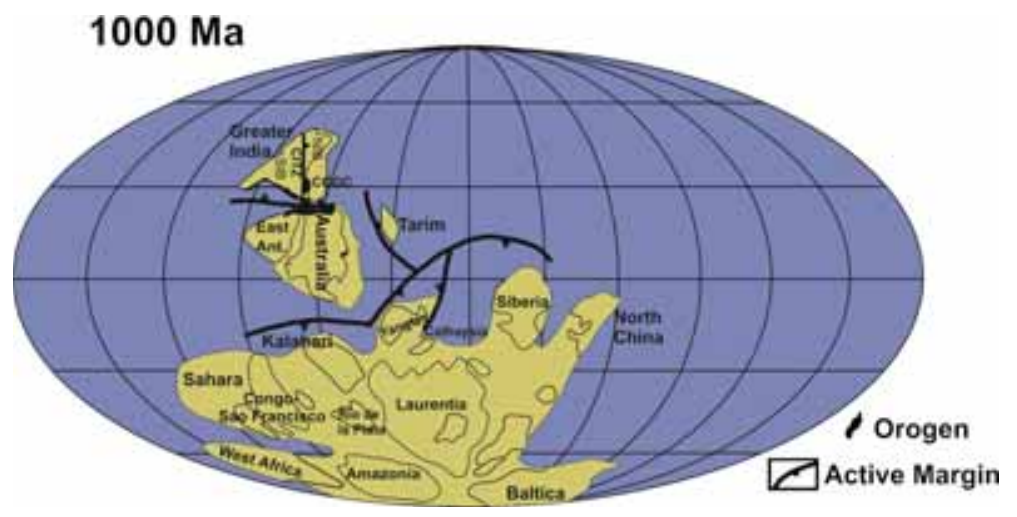

Figure 9. Cartographic picture showing the Rodinia assembly and position of India at $1000 \mathrm{Ma}$ (modified after Li et al. 2008).

\subsection{Implications for the supercontinental history}

The age of formation, amalgamation and reconstruction of central and eastern Indian terrain generates essential information regarding the palaeogeographic condition of supercontinents. Rogers and Santosh (2002) proposed that the Columbia supercontinent amalgamation initiated 1900-1800 Ma and achieved their highest packing strength at 1600-1500 Ma and started to rift after 1500 Ma. During this rifting period a lot of magmatic processes were obtained, viz., crystallisation of anorthosite around $1550 \mathrm{Ma}$ (Chatterjee et al. 2008), khondalite emplaced in the quartzo-feldspathic matrix around 1510 Ma (Sanyal et al. 2007), as well as charnockite gneiss emplacement during $1457 \pm 63 \mathrm{Ma}$ (Ray Barman et al. 1994). The development of Rodinia started from the Grenvillian orogenic age 1100-900 Ma, and drifting was started after $750 \mathrm{Ma}$. The number of configurations and models of the Rodinia supercontinent have been proposed by different scientists, including Dalziel (1991), Hoffman (1991), Rogers (1996), Meert (2001), Wingate et al. (2002) and $\mathrm{Li}$ et al. (2008). The age of fragmentation from 1200 to 800 Ma was interpreted within the southern Indian granulite blocks (Yoshida et al. 2003) at some locations. Ghose (1983) and Banerji (1991) mentioned orogenic phases in the CGGC, named as the Chhotanagpur orogeny (1600-1500 Ma) and the Satpura orogeny (900-850 Ma). However, the CGGC of eastern India shows a shred of evidence of the Grenvillianorogeny age at 1100-900 Ma which is strongly preserved, and it postulates that the Grenvillianorogeny suture was very near the CGGC of India. In the previously proposed models, Greater India was emplaced along the western side of East
Antarctica and the SW part of Australia to produce a substantial accretionary mass of western Rodinia (Dalziel 1991; Hoffman 1991; Moores 1991). They suggested that India was assembled with the Rodinia supercontinent through the continent-continent collision between 1000 and $900 \mathrm{Ma}$ along the Eastern Ghats mobile belt (EGMB) and CGGC of the Indian subcontinent which corresponds to East Antarctica's Rayner Province. Li et al. (2008) explained the palaeolatitudinal position between Greater India and the Australian land mass at $\sim 770-750 \mathrm{Ma}$ age due to the drifting of the Indian plate away from the Australia-East Antarctica continental plate by ca. 755 Ma. The transpressional movement of the Indian and Australian continental plates may explain the 1100-1000 Ma metamorphic events investigated from the Pinjarra orogen (Bruguier et al. 1999; Fitzsimons 2003). The ( 1424 Ma) older age reveals the age of emplacement of felsic magmatism similar to the rocks of the other area of the CGGC that has been mentioned in table 1 . This rock was assumed to be the protolith of granulitic gneiss, which was formed by the highgrade metamorphism under granulite facies conditions ('Grenville-age' orogenesis, 1000-900 Ma) during $\mathrm{M}_{3}$ in Daltonganj, presumably during the assembly of Rodinia. The 1000 Ma high-grade metamorphism gives evidence of tectono-metamorphic episodes in the CGGC, CITZ and EGMB of India (figure 9).

\section{Conclusion}

The CGGC represents a complex metamorphic history, where Mesoproterozoic metamorphism was overlain by high-grade metamorphism of Grenvillian-orogeny (1100-900 Ma). The CGGC 
terrain mainly contains high-grade amphibolite facies to granulite facies rocks, which lies between two medium- to low-grade mobile belts. The northwestern part of the CGGC depicts that the protolith of granulitic gneiss had been emplaced around $1424 \mathrm{Ma}$ age and subsequently transformed by a high-grade metamorphic event at 972 Ma. High-grade metamorphism at 972-962 Ma from the Daltonganj area of the north-western CGGC suggests connecting link between the Satpura mobile belts of CITZ in Grenvillian-orogeny. The $P-T$ condition calculated in the present study perhaps corresponds to initial heating and compression until achieving a peak metamorphic condition. The prograde metamorphic condition in the Daltonganj area of the CGGC at the $\mathrm{M}_{3}$ metamorphic event has reported $7.35 \mathrm{kbar} / 792^{\circ} \mathrm{C}$ in the Grenvillian age. Thus, Grenvillian metamorphism was well documented in the CGGC, where Greater India was part of the Rodinia supercontinent.

\section{Acknowledgements}

We are thankful to the Director, Indian Institute of Technology (BHU) for providing the infrastructure and funds to complete this work. R Kumar is also grateful to the UGC-JRF scheme for providing financial support for the present work. The authors express their gratitude to Prof N V Chalapathi Rao and Dr Dinesh Pandit from Mantle Petrology Laboratory, Department of Geology, Centre of Advanced Study, Institute of Science, BHU, for providing the EPMA and SEM analyses facility. We are also thankful to the Associate Editor, Prof $\mathrm{P}$ Sengupta and the anonymous reviewers for their constructive comments and useful suggestions to improve the quality of the manuscript.

\section{References}

Acharyya S K 2003 The nature of Mesoproterozoic central Indian tectonic zone with exhumed and reworked older granulites; Gondwana Res. 6(2) 197-214.

Aranovich L Ya and Podlesskii K K 1983 The cordieritegarnet-sillimanite equilibrium: Experiments and application; In: Kinetics and equilibrium in mineral reactions (ed.) Saxena S K, Springer, New York, Berlin, Heidelberg, Tokyo, pp. 173-198.

Aranovich L Ya and Podlesskii K K 1989 Geothermobarometry of high-grade metapelites: Simultaneously operating reactions; In: Evolution of metamorphic belts (eds) Cliff $\mathrm{R}$ A, Yardley B D and Daly J S, Blackwell Scientific Publications, Oxford; Geol. Soc. Spec. Publ. 43 45-61.
Bhattacharya A, Mazumdar A C and Sen S K 1988 Fe-Mg mixing in cordierite: Constraints from natural data and implications for cordierite-garnet geothermometry in granulites; Am. Mineral. 73 338-344.

Banerji A K 1991 Presidential address. Geology of the Chhotanagpur region; Indian J. Geol. 63 275-282.

Bhowmik S K, Bernhardt H J and Dasgupta S 2010 Grenvillian age high-pressure upper amphibolite Granulite metamorphism in the Aravalli-Delhi Mobile Belt, Northwestern India: New evidence from monazite chemical age and its implication; Precamb. Res. 178 168-184.

Bhowmik S K, Wilde S A, Bhandari A and Sarbadhikari A B 2014 Zoned Monazite and zircon as monitors for the thermal history of Granulite Terranes: An example from the central Indian tectonic zone; J. Petrol. 55 585-621.

Braun I, Montel J M and Nicollet C 1998 Electron microprobe dating of monazites from high-grade gneisses and pegmatites of the Kerala Khondalite Belt, southern India; Chem. Geol. 146 65-85.

Bruguier O, Bosch D, Pidgeon R T, Byrne D I and Harris L B $1999 \mathrm{U}-\mathrm{Pb}$ chronology of the Northampton complex, Western Australia: Evidence for Grenvillian sedimentation, metamorphism and deformation and geodynamic implications; Contrib. Mineral. Petrol. 136 258-272.

Cocherie A, Legendre O, Peucat J J and Kouamelan A 1997 In-situ Th-U-Pb dating using an electron microprobe: $\mathrm{A}$ powerful tool for complex polygenic monazites; Terra Abst. 9441.

Chatterjee N, Crowley J L and Ghose N C 2008 Geochronology of the $1.55 \mathrm{Ga}$ Bengal anorthosite and Grenvillian metamorphism in the Chhotanagpur gneissic complex, eastern India; Precamb. Res. 161 303-316.

Chatterjee N, Banerjee M, Bhattacharya A and Maji A K 2010 Monazite chronology, metamorphism-anatexis and tectonic relevance of the mid-Neoproterozoic Eastern Indian tectonic zone; Precamb. Res. 179 99-120.

Chatterjee N and Ghose N C 2011 Extensive early Neoproterozoic high-grade metamorphism in North Chhotanagpur gneissic complex of the central Indian tectonic zone; Gondwana Res. 20 362-379.

Dalziel I W D 1991 Pacific margins of Laurentia and East Antarctica-Australia as a conjugate rift pair: Evidence and implications for an Eocambrian supercontinent; Geology 19(6) 598-601.

Dasgupta S and Sengupta P 2003 Indo-Antarctic correlation: A perspective from the Eastern Ghats Granulite Belt, India; In: Proterozoic East Gondwana: Supercontinent assembly and breakup (eds) Yoshida M, Windley B E, Dasgupta S, Geol. Soc. London, Spec. Publ. 206 131-143.

Dwivedi S B, Mohan A and Lal R K 1998 Recalibration of $\mathrm{Fe}-\mathrm{Mg}$ exchange reaction between garnet and cordierite as a thermometer; Eur. J. Mineral. 10 281-289.

Dwivedi S B, Kumar R R and Srivastava M 2019 Multistage gedrite in gedrite-hypersthene bearing high-grade granulites from Daltonganj, Chhotanagpur granite gneissic complex, Jharkhand, as evident from TEM and textural relations; J. Earth Syst. Sci. 128(41) 1-14.

Fitzsimons I C W 2003 Proterozoic basement provinces of southern and southwestern Australia, and their correlation with Antarctica; Geol. Soc. London, Spec. Publ. 206 93-130. 
Frost C D and Frost B R 2011 On ferroan (A-type) granitoids: Their compositional variability and modes of origin; J. Petrol. 52 39-53.

Ghose N C 1983 Geology, tectonics and evolution of the Chhotanagpur granite-gneiss complex, Eastern India; In: Structure and tectonics of Precambrian Rocks of India (ed.) Sinha-Roy S, Recent Res. Geol. v.10, Hindustan Publ. Corp., Delhi, pp. 211-247.

Ghose N C 1992 Chhotanagpur gneiss-granulite complex, Eastern India: Present status and future prospect; Indian J. Geol. 84 100-121.

Hoffman P F 1989 Speculations on Laurentia's first giga year (2.0 to $1.0 \mathrm{Ga})$; Geology 17 135-138.

Hoffman P F 1991 Did the breakout of Laurentia turn Gondwanaland inside out? Science 252 1409-1412.

Holdaway M J and Lee S M 1977 Fe-Mg cordierite stability in high natural pelitic rocks based on experimental, theoretical and natural observations; Contrib. Mineral. Petrol. 63 $175-198$.

Holland T J B and Powell R 1998 An internally-consistent thermodynamic dataset for phases of petrological interest; J. Met. Geol. 16 309-344.

Karmakar S, Bose S, Sarbadhikari A B and Das K 2011 Evolution of granulite enclaves and associated gneisses from Purulia, Chhotanagpur granite gneiss complex, India: Evidence for 990-940 Ma tectonothermal event(s) at the eastern India cratonic fringe zone; J. Asian Earth Sci. 41 69-88.

Lal R K 1991 Ti content of mica as a geothermobarometry; In: Third Indo-Soviet Symposium on Experimental Mineralogy and Petrology, New Delhi, pp. 13-15.

Li Z X, Bogdanova S V, Collins A S, Davidson A, De Waele B, Ernst R E, Fitzsimons I C W, Fuck R A, Gladkochub D P, Jacobs J, Karlstrom K E, Lu S, Natapov L M, Pease V, Pisarevsky S A, Thrane K and Vernikovsky V 2008 Assembly, configuration, and breakup history of Rodinia: A synthesis; Precamb. Res. 160 $179-210$.

Ludwig K R 2011 Isoplot 3.70 (version-4): A geochronological toolkit for microsoft excel; Berkeley Chronology Center, Berkeley, California, Special Publication 4.

Maji A K, Goon S, Bhattacharya A, Mishra B, Mahato S and Bernhardt H J 2008 Proterozoic polyphase metamorphism in the Chhotanagpur gneissic complex (India) and implication for trans-continental Gondwanaland correlation; Precamb. Res. 162 385-402.

Mallik A K, Gupta S N and Ray Barman T 1991 Dating of early Precambrian granite-greenstone complex of the Eastern Indian Precambrian shield with special reference to the Chhotanagpur granite gneiss complex; Rec. Geol. Survey India 124 20-21.

Meert J G 2001 Growing Gondwana and rethinking Rodinia: A paleomagnetic perspective; Gondwana Res. 4(3) 279-288.

Mezger K and Cosca M A 1999 The thermal history of the Eastern Ghats Belt (India) as revealed by U-Pb and ${ }^{40} \mathrm{Ar} /{ }^{39} \mathrm{Ar}$ dating of metamorphic and magmatic minerals: Implications for the SWEAT correlation; Precamb. Res. 94 251-271.

Montel J M, Veschambre M and Nicollet C 1994 Datation de la monazite a la microsonde électronique; Comptes Rendus academie des sciences parisserie 2 sciences de la terre et desplanetes fascicule a. 318 1489-1495.
Montel J, Foret S, Veschambre M, Nicollet C and Provost A 1996 Electron microprobe dating of monazite; Chem. Geol. $13137-53$.

Moores E M 1991 Southwest US-east antarctic (SWEAT) connection: A hypothesis; Geology 19 425-428.

Mukherjee S, Dey A, Sanyal S, Ibanez-Mejia M, Dutta U and Sengupta P 2017 Petrology and U-Pb geochronology of zircon in a suite of charnockitic gneisses from parts of the Chhotanagpur granite gneiss complex (CGGC): Evidence for the reworking of a Mesoproterozoic basement during the formation of the Rodinia supercontinent; In: Crustal evolution of India and Antarctica: The supercontinent connection, Geological Society of London, special publications (eds) Pant N C and Dasgupta S, Geol. Soc. London, Spec. Publ., https://doi.org/10.1144/sp457.6.

Mukherjee S, Dey A, Ibanez-Mejia M, Sanyal S and Sengupta P 2018 Geochemistry, U-Pb geochronology and Lu-Hf isotope systematics of a suite of ferroan (A-type) granitoids from the CGGC: Evidence for Mesoproterozoic crustal extension in the east Indian shield; Precamb. Res. 305 40-63.

Nichols G T, Berry R F and Green D H 1992 Internally consistent gahnitic spinel cordierite-garnet equilibria in the FMASHZn system: Geothermobarometry and application; Contrib. Mineral. Petrol. 111 362-377.

Pabst A and Hutton C O 1951 Huttonite, a new monoclinic thorium silicate; Am. Mineral. 36 60-69.

Pandey B K, Upadhyaya L D and Sinha K K 1986a Geochronology of Jajawal-Binda-Nagnaha granitoids in relation to uranium mineralization; Indian J. Earth Sci. 13 163-168.

Pandey B K, Gupta J N and Lall Y 1986b Whole rock and mineral $\mathrm{Rb}-\mathrm{Sr}$ isochron ages for the granites from Bihar mica belt of Hazaribagh, Bihar, India; Indian J. Earth Sci. 13 157-162.

Pandey M, Pandit D, Arora D, Chalapathi Rao N V and Pant N C 2019 Analytical protocol for U-Th-Pb chemical dating of monazite using CAMECA SX Five EPMA installed at the Mantle Petrology Laboratory, Department of Geology, Banaras Hindu University, Varanasi, India; J. Geol. Soc. India 93 46-50.

Parrish R R 1990 U-Pb dating of monazite and its application to geological problems; Can. J. Earth Sci. 27 760-763.

Perchuk L L 1991 Derivation of a thermodynamically consistent set of geothermometers and geobarometers for metamorphic and magmatic rocks; In: Progress in metamorphic and magmatic petrology (A memorial volume in honor of $D S$ Korzhinsky) (ed.) Perchuk L L, Cambridge University Press, Cambridge, pp. 93-112.

Perchuk L L, Aranovich L Ya, Podlesskii K K and Lavrenteva I V 1985 Precambrian granulites of the Alden Shield. Eastern Siberia USSR; J. Met. Geol. 3 265-310.

Prabhakar N 2013 Resolving poly-metamorphic Paleoarchean ages by chemical dating of monazites using multispectrometer $\mathrm{U}, \mathrm{Th}$ and $\mathrm{Pb}$ analyses and sub-counting methodology; Chem. Geol. 347 255-270.

Ray Barman T and Bishui P K 1994 Dating of Chhotanagpur gneissic complex of eastern Indian Precambrian shield; Rec. Geol. Surv. India 127(2) 25-27.

Ray Barman T, Bishui P K and Mukhopadhyay Ray J N 1994 Rb-Sr geochronology of the high-grade rocks from Purulia, 
West Bengal and Jamua-Dumka sector, Bihar; Indian Mineral. 48 45-60.

Roy A and Devarajan M K 2000 A reappraisal of the stratigraphy and tectonics of the Palaeoproterozoic Mahakoshal supracrustal belt, Central India. Proceedings of the International Seminar on Precambrian Crust in Eastern and Central India, UNESCOIUGS-IGCP 368; Geol. Surv. India, Spec. Publ. 57 79-97.

Rode K P 1948 On the charnockite rocks of Palamau, Bihar, India; Schweizerische Mineralogische and Petrographische Mitteilungen. 28 288-302.

Rogers J J W 1996 A history of continents in the past three billion years; J. Geol. 104 91-107.

Rogers J J W and Santosh M 2002 Configuration of Columbia, a Mesoproterozoic supercontinent; Gondwana Res. 5 5-22.

Rosa-Costa L T D, Lafon J M, Cocherie A and Delor C 2008 Electron microprobe $\mathrm{U}-\mathrm{Th}-\mathrm{Pb}$ monazite dating of the Transamazonian metamorphic overprint on Archean rocks from the Amapá Block, southeastern Guiana Shield, Northern Brazil; J. South Am. Earth Sci. 26 445-462.

Rose D 1980 Brabantite, $\mathrm{CaTh}\left[\mathrm{PO}_{4}\right]_{2}$, a new mineral of the monazite group; Neues Jahrb. Mineral., Monatsh. 6 247-257.

Saha A K 1994 Crustal evolution of Singhbhum-North Orissa, Eastern India; J. Geol. Soc. India Memoir 27341.

Saikia A, Gogoi B, Kaulina T, Lialina L, Bayanova T and Ahmad M 2017 Geochemical and U-Pb zircon age characterization of granites of the Bathani Volcano Sedimentary sequence, Chhotanagpur granite gneiss complex, eastern India: Vestiges of the Nuna supercontinent in the central Indian tectonic zone; In: Crustal evolution of India and Antarctica: The supercontinent connection (eds) Pant N C and Dasgupta S, Geol. Soc. London, Spec. Publ. 457.

Sanyal S, Sengupta P and Goswami R 2007 Evidence of Mesoproterozoic ultra-high temperature Metamorphism from parts of CGGC, Jharkhand, India; In: Abstract volume of the International Conference on Precambrian sedimentation and tectonics and second GPSS meeting, Indian Institute of Technology, Bombay, pp. 62-63.

Sanyal S and Sengupta P 2012 Metamorphic evolution of the Chhotanagpur granite gneiss complex of the East Indian Shield: Current status; In: Palaeoproterozoic of India (eds) Mazumder R and Saha D, Geol. Soc. London, Spec. Publ. 365 117-145.

Sarkar S N 1980 Precambrian stratigraphy and geochronology of Peninsular India: A review; Indian J. Earth Sci. 7 12-26.

Schaltegger U, Fanning C M, Gunther D, Maurin J C, Schulmann K and Gebauer D 1999 Growth, annealing and recrystallization of zircon and preservation of monazite in high-grade metamorphism: Conventional and in-situ $\mathrm{U}-\mathrm{Pb}$ isotope, cathodoluminescence and microchemical evidence; Contrib. Mineral. Petrol. 134 186-201.

Shaw R K, Arima M, Kagami H, Fanning C M, Shiraishi K and Motoyoshi Y 1997 Proterozoic events in the Eastern Ghats Granulite Belt, India: Evidence from $\mathrm{Rb}-\mathrm{Sr}, \mathrm{Sm}-\mathrm{Nd}$ systematics, and shrimp dating; J. Geol. 105 645-656.
Singh R N, Thorpe R and Kristic D 2001 Galena Pb isotope date of base metal occurrences in the Hesatu-Belbathan belt, eastern Precambrian shield, Bihar; J. Geol. Soc. India 57 535-538.

Singh Y and Krishna V 2009 Rb-Sr Geochronology and petrogenesis of granitoids from the Chhotanagpur granite gneiss complex of Raikera-Kunkuri region, central India; J. Geol. Soc. India. 74 200-208.

Spear F S and Pyle J M 2010 Theoretical modeling of monazite growth in a low-Ca metapelite; Chem. Geol. 273 111-119.

Suzuki K and Adachi M 1991 Precambrian provenance and Silurian metamorphism of the Tsubonasawa paragneiss in the South Kitakami terrane, Northeast Japan, revealed by the Chemical Th-U total lead isochron ages of monazite, zircon and xenotime; Geochem. J. 25 357-376.

Suzuki K and Adachi M 1994 Middle Precambrian detrital monazite and zircon from the Hida gneiss on Oki-Dogo island, Japan: Their origin and implications for the correlation of basement gneiss of Southwest Japan and Korea; Tectonophys. 235 277-292.

Thompson A B 1976 Mineral reactions in pelitic rocks: I. Prediction of $\mathrm{P}-\mathrm{T}-\mathrm{X}(\mathrm{Fe}-\mathrm{Mg})$ phase relations. II. Calculations of some P-T-X (Fe-Mg) phase relations; Am. J. Sci. 276 401-454.

Wells P R A 1979 Chemical and thermal evolution of Archean sialic crust, southern Greenland; J. Pet. 20 187-226.

Wells P R A and Richardson S W 1980 Thermal evolution of metamorphic rocks in the central Highlands of Scotland; In: The Caledonides of the British Isles-reviewed (eds) Harris A L, Holland C H and Leake B E, Geol. Soc. London, Spec. Publ. 8 339-344.

Whitney D L and Evans B W 2010 Abbreviations for names of rock-forming minerals; Am. Mineral. 95 185-187.

Williams M L, Jercinovic M J and Terry M 1999 High resolution 'age' mapping, chemical analysis, and chemical dating of monazite using the electron microprobe: A new tool of tectonic analysis; Geology 27 1023-1026.

Wingate M T D, Pisarevsky S A and Evans D A D 2002 Rodinia connections between Australia and Laurentia: No SWEAT, no AUSWUS? Terra Nova 14 121128.

Yadav B S, Wanjari N, Ahmad T and Chaturvedi R 2016 Geochemistry and petrogenesis of Proterozoic granitic rocks from northern margin of the Chhotanagpur gneissic complex (CGC); J. Earth Syst. Sci. 125 1041-1060.

Yoshida M, Funaki M and Vitanage P W 1992 Proterozoic to Mesozoic East Gondwana: The Juxtaposition of India, Sri Lanka, and Antarctica; Tectonics 11 381-391.

Yoshida M, Jacobs J, Santosh M and Rajesh H M 2003 PanAfrican events in the Circum-East Antarctic Orogen of East Gondwana: A critical overview; In: Proterozoic East Gondwana: Supercontinent assembly and breakup (eds) Yoshida M, Windley B F and Dasgupta S, Geol. Soc. London, Spec. Publ. 206 57-75. 